GEOLOGICAL SURVEY CIRCULAR 340

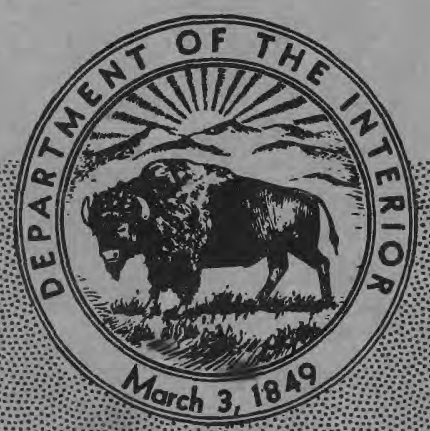

WATER RESOURCES OF THE

WHEELING-STEUBENVILLE AREA WEST VIRGINIA AND OHIO

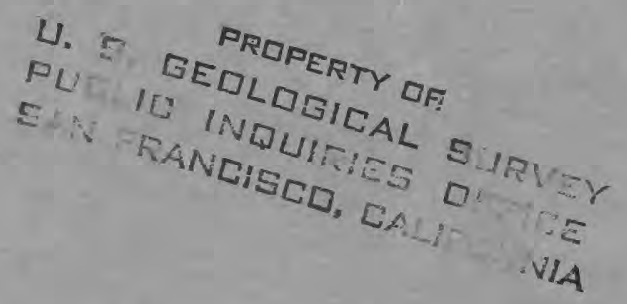



UNITED STÁTES DEPARTMENT OF THE INTERIOR

Douglas McKay, Secretary

GEOLOGICAL SURVEY

W. E. Wrather, Director

GEOLOGICAL SURVEY CIRCULAR 340

\section{WATER RESOURCES OF THE WHEELING-STEUBENVILLE AREA WEST VIRGINIA AND OHIO}

By R. C. Smith, W. L. Doll, and Garland Stratton 


\section{PREFACE}

This report is one of a series concerning watersupply conditions in certain selected areas of national importance and has been prepared at the request of the Business and Defense Services Administration of the U. S. Department of Commerce. It is intended to provide information of value for national defense and related purposes as well as basic data on water resources of the Wheeling-Steubenville area. The series is being prepared in the Water Resources Division of the U. S. Geological Survey with the assistance of J. B. Graham and K. A. MacKichan of the Water Utilization Section of the Technical Coordination Branch. This report was prepared by W. L. Doll, hydraulic engineer, under the supervision of A. A. Fischback, $\mathrm{Jr}$., district engineer in West Virginia (Surface Water Branch); R. C. Smith, formerly geologist-in-charge in West Virginia (Ground Water Branch); and Garland Stratton, chemist, under the supervision of $W$. L. Lamar, district chemist (Quality of Water Branch).

The water-resources data summarized in this report have been gathered over a period of many years by Federal, State, and local agencies, as well a private organizations, in connection with reports and investi- gations for water development in the Ohio River Valley. Some of the basic water-resources data used in this report have been collected by the U. S. Geological Survery in Ohio in cooperation with the Ohio Department of Natural Resources, Division of Water, and in West Virginia in cooperation with West Virginia Water Commission, West Virginia Conservation Commission, West Virginia Geological Survey, and West Virginia Public Service Commission, and the U. S. Corps of Engineers (Pittsburgh District).

Other data and information are from technical reports of the U. S. Corps of Engineers; U. S. Weather Bureau; U. S. Public Health Service; State Departments of Health of Ohio and West Virginia; West Virginia State Water Commission; Ohio Department of Natural Resources, Division of Water; and other agencies.

The Corps of Engineers furnished data for Ohio River profiles, records of historical floods, and data on proposed flood protection works. Many valuable water analyses were furnished by the city of Wheeling, $W$. Va., the Weirton Steel Co., and the Beech Bottom Power Co. 


\section{CONTENTS}

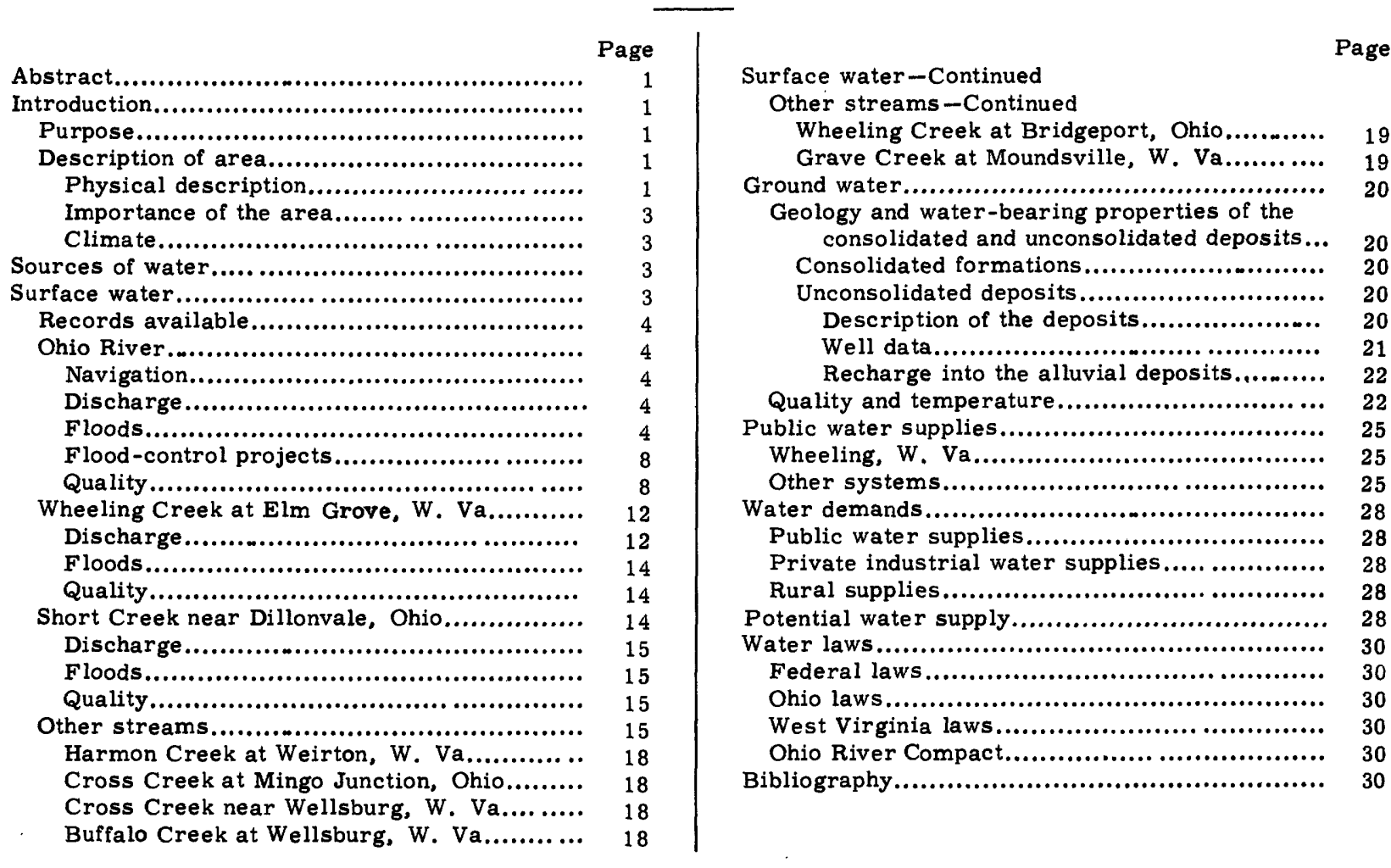

\section{ILLUSTRATIONS}

Page

Plate 1. Map showing the water resources of the Wheeling-Steubenville area................................... In pocket

Figure 1. Precipitation and air temperature at Wheeling (lock and dam 12).

2. Maximum, minimum, and average monthly discharge of the Ohio River at Bellaire, $1942-52 \ldots \ldots . . . .$.

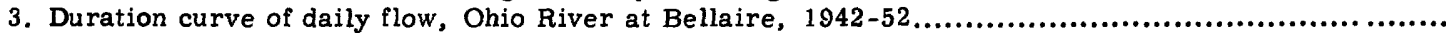

4. Flood-stage frequencies, Ohio River at Wheeling (lock and dam 12), 1838-1952.

5. Water-surface profiles of selected floods on the Ohio River between lock and dam 9 and lock and dam 14

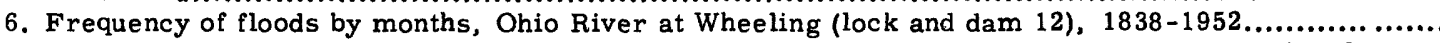

7. Cumulative frequency curve of hardness, Ohio River water at Wheeling and Weirton, $1948-52 \ldots . . .$.

8. Relation between streamflow and chemical and physical properties of the water, Ohio River at Power, 1952.

9. Cumulative frequency curve of water temperature, Ohio River at Weirton, Power, and Wheeling....

10. Maximum, minimum, and average monthly flow, Wheeling Creek at Elm Grove, $1941-52 \ldots . . . . . . . .$.

11. Duration curve of daily flow, Wheeling Creek at Elm Grove...........................................

12. Maximum, minimum, and average monthly flow, Short Creek near Dillonvale, Ohio, $1942-52 \ldots . . . .$.

13. Duration curve of daily flow, Short Creek near Dillonvale.

14. Chemical quality of water from selected small streams

15. Computed duration curve of daily flow, Cross Creek at Mingo Junction, Ohio, and Cross Creek at Wellsburg, W. Va., 1932-52.

16. Computed duration curve of daily flow, Buffalo Creek at Wellsburg, W, Va. ; Wheeling Creek at Bridgeport, Ohio; and Grave Creek at Moundsville, W. Va. ; $1932-52$

17. Generalized cross sections of the Ohio River Valley showing the occurrence of the unconsolidated deposits

18. The relationship between the water level in an observation well at the Triangle Conduit and Cable Co. at Glen Dale, pumpage from the company well field, and river level at Bellaire..... 
Figure 19. Composition of water from selected public water supplies in the Wheeling-Steubenville area..........

20. Predicted increase in the demand for water from the Wheeling public supp ly...........................

\section{TABLES}

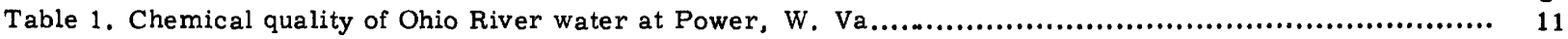

2. Chemical quality of water from selected streams....................................................... 14

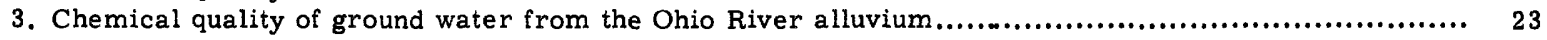

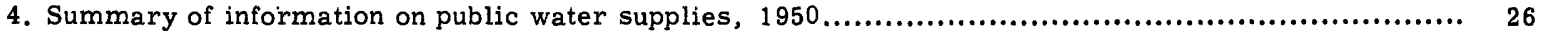

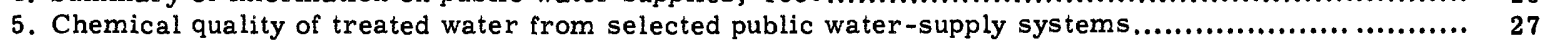

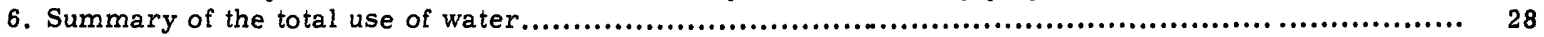




\title{
WATER RESOURCES OF THE WHEELING-STEUBENVILLE AREA WEST VIRGINIA AND OHIO
}

\author{
By R. C. Smith, W. L. Doll, and Garland Stratton
}

\begin{abstract}
Sufficient water is available in the WheelingSteubenville area to meet any forseeable demands. The Ohio River will supply large and dependable quantities of surface water for municipalities in the Ohio River Valley. The average flow of the Ohio River at Bellaire, Ohio, for 11 years (1942-52) was 27, 140 million gallons per day (mgd). The total water withdrawn, both ground water and surface water, was about $950 \mathrm{mgd}$, or less than 3.5 percent of the mean flow of the Ohio River. A large percentage of the water is used for cooling and is pumped through the plants and returned to the river unchanged except for a slight rise in temperature.
\end{abstract}

Only 5 of 19 municipalities having public water supplies use surface water; however, since 4 of the 5 are the largest cities in the area, more than 70 percent of the water used for public supplies is from surface sources. The 3 largest cities obtain water from the Ohio River.

The tributary streams average approximately 140 square miles in drainage area. Stream-gaging stations are maintained on two of the tributaries, and the lowflow characteristics of some of the ungaged tributaries were computed from available data. The flows vary widely from flood to drought, but even during low flows the quantity of water available is sufficient for many uses. The low flows could be augmented by storage. Ground water is used by 14 communities for their public water supply. Many of the smaller industries have developed their own ground-water supply, and some of the large industries augment their surface-water supply with ground water because the ground water has a more uniform temperature. Induced infiltration in the alluvium in the valley of the Ohio River is the principal source of large quantities of the ground water.

It is believed that by using induced infiltration there would be a maximum ground-water potential of about $350 \mathrm{mgd}$ in the 34 miles of river front that can be considered favorable for the development of large groundwater supplies. At present approximately $35 \mathrm{mgd}$, or about 10 percent of the estimated maximum groundwater potential of the area, is being withdrawn.

Although the mineral content of the ground water is lower than that of some of the small streams, it is higher than the mineral content of the Ohio River. The observed hardness of the ground water ranged from a little less than 200 to more than 800 parts per million (ppm), expressed as $\mathrm{CaCO}_{3}$, as compared with 115 to more than $1,000 \mathrm{ppm}$ for the small streams and slightly more than 50 to slightly more than $270 \mathrm{ppm}$ for the Ohio River. Water from the Pleistocene and Recent alluvium has a higher $\mathrm{pH}$ than Ohio River water.

\section{INTRODUCTION}

Purpose and Scope

The purpose of this report is to present and interpret all available water-resources information for the Wheeling-Steubenville area. Essentially all of the present industrial development of the area is included. The information will be useful for initial guidance in the location or expansion of water facilities for industries and the municipalities upon which they are dependent. It is hoped that it may also prove of value to municipalities or other agencies that have water-supply or pollution problems. This report is not expected to provide the final answer to all the questions that may arise in connection with the water resources of the area. Sufficient data are not at hand from which it would be possible to determine the amount of ground water that could be obtained in any particular area; however, reasonable approximations of the quantity and quality of ground-and surface-water resources have been made.

\section{Description of Area}

Physical Description

This rectangular area, roughly centered on the city of Wheeling, W. Va., is about 35 miles long from north to south and 19 miles wide from eașt to west and includes parts of Ohio and West Virginia. (See pl. 1.) The cities of Steubenville, Ohio, and Wheeling and Weirton, W. Va., are included. The area is shown on parts of six U. S. Geological Survey topographic maps: the Cadiz, Cameron, Clarington, St. Clairville, Steubenville, and Wheeling quadrangles.

The area is within the Appalachian Plateaus physiographic province, although it has been so deeply dissected by streams that all that remains of the plateaus are the levels represented by the hilltops. The topography can best be described as rugged, with narrow steep-sided ridges separated by narrow $\mathrm{V}$-shaped valleys. Altitudes range from more than 1,300 feet to less than 600 feet above sea level; local relief exceeds 600 feet in some places.

The Ohio River, flowing southwestward across the area, has cut a relatively wide $U$-shaped valley that is in striking contrast to the surrounding hills. The river meanders within the valley and is bordered by a flood plain. The walls of the valley rise very abruptly, and the tops of the immediately adjacent hills are nearly 500 feet above the river level in many places.

The majority of the tributaries are short and flow in steeply sloping valleys without flood plains. However, 

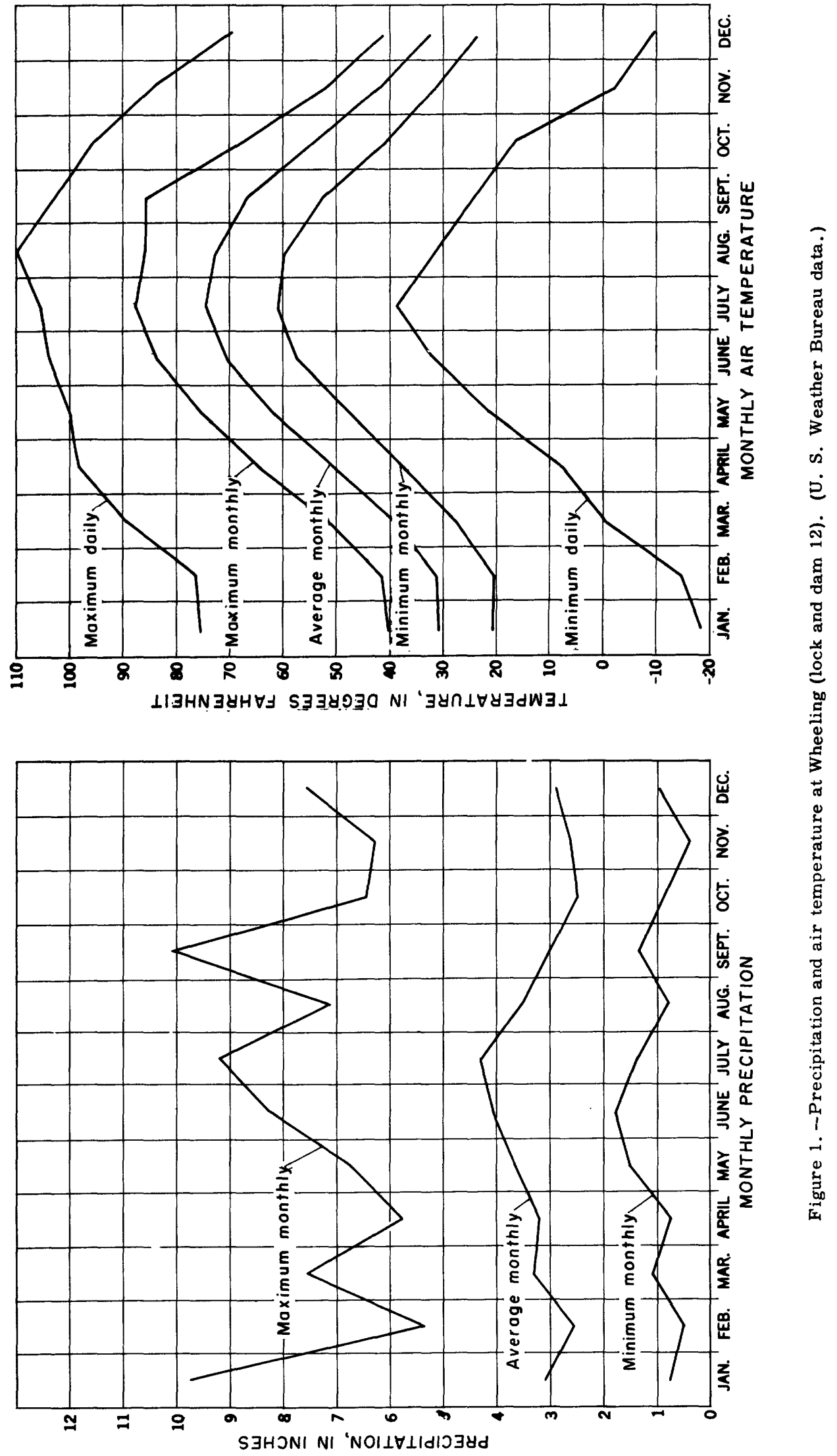
McMahon, Wheeling, and Short Creeks in Ohio, and Wheeling and Buffalo Creeks in West Virginia, have cut valleys in which the streams, particularly in their lower portions, are bordered by minor flood plains.

\section{Importance of the Area}

The Wheeling-Steubenville area is an important industrial center. Steel is its principal industry, and coal mining its second industry. Other industries include the manufacture of glassware, pottery, and chemicals. Wheeling is a center for the manufacture of tobacco products. The area is served by 5 railroads and 3 major passenger airlines. The Ohio River is an important artery for freight traffic. According to the Ohio River Division of the Corps of Engineers, river transportation to and through the area amounted to $7,200,000$ tons in 1951. This is an increase of approximately 60 percent over that carried in 1948. The commodities carried were chiefly oil and gasoline, 2, 500,000 tons; coal and coke, 2,000,000 tons; and iron and steel, 1,750,000 tons. Natural resources of the area include coal, oil, gas, ceramic clays and shales, and brine. Factors contributing to the importance of the area are excellent transportation, principally on the Ohio River; coal, mined within the area and in nearby areas; and the availability of water.

The population, about 250,000 people, is divided about equally between the metropolitan areas of Wheeling and Steubenville. Topography has been the prime factor controlling the location and size of the centers of population-although there are some communities in the uplands away from the Ohio River, by far the majority of the towns are in the valleys.

\section{Climate}

The climate of the Wheeling-Steubenville area is about average for Pennsylvania and Ohio. Extremes of heat or cold and long rainy periods or extreme droughts are uncommon. Precipitation is well distributed throughout the year. Figure 1 shows the range in precipitation and temperature. The graphs were prepared from data collected at Wheeling (Ohio River lock and dam 12) by the U. S. Weather Bureau.

The average annual precipitation is about 39 inches, according to 45 years of record. Extremes for the last 68 years ranged from 64.28 inches in 1890 to 24.08 inches in 1930 . The average annual temperature is $52.7^{\circ} \mathrm{F}$. The average frost-free growing season is about 177 days. Dense fogs are quite prevalent in the valleys.

\section{SOURCES OF WATER}

The ultimate source of all the water in any area is precipitation in the form of rain, snow, ice, and dew that falls on or near the area. Water in the lakes, streams, and beneath the ground is continually moving as a part of a great cycle-the hydrologic cycle. This cycle is the path taken by a drop of water as it moves from the atmosphere to the ground, or to bodies of water, and back to the atmosphere.
The paths taken by the many drops of water after they reach the ground differ greatly. Some of the water may evaporate immediately and thus complete the cycle quickly. Some of the water falls directly into ponds, lakes, and streams and either evaporates or flows toward the oceans. Some of the water runs of the land surface into streams and lakes, and some of the water enters the soil. Of the water that enters the soil, a part will replenish the soil moisture and will be evaporated or transpired to the atmosphere by the plants. The remainder of the water that enters the soil percolates downward to become ground water. The groundwater body is not static but is continually discharging or being recharged. Ground-water discharge seeps into the streams at rates that vary according to the quantity of ground water in storage. Ground-water discharge constitutes most of the dry-weather flow of streams.

The amount of water following any of these paths depends on many factors. Much of the precipitation falling after long periods of dry weather will be absorbed by the soil. In areas covered by tight, impervious clay or underlain by impervious rocks, much of the precipitation will drain into the surface bodies of water. In areas of rugged topography much of the precipitation will flow quickly down the hillsides and enter the streams; much of the water that does enter the ground will soon discharge from the hillsides. In areas underlain by porous material, or in relatively flat areas, a higher percentage of the precipitation will become ground water. Thus, the amount of water available in any one area depends upon the amount and the distribution of the precipitation, the topography, and the geology of the area.

Surface water (streams and lakes) and bodies of ground water are the most important sources of water. Ground water, however, is less subject to wide variations in quantity, quality., and temperature and rarely contains suspended sediment and waste, although it is of ten more highly mineralized than surface water.

Principal sources of water in the WheelingSteubenville area are the Ohio River and the gravels beneath the flood plain adjacent to the Ohio River. (See pl. 1.) Some water is available from Harmon, Cross, Buffalo, Wheeling, and Grave Creeks in West Virginia, and from Cross and Wheeling Creeks in Ohio. There are no lakes in the area, although the Ohio River is maintained as a series of pools behind the navigation locks and dams.

\section{SURFACE WATER}

The Ohio River is by far the most important river in the Wheeling-Steubenville area. It provides a large quantity of surface water for water supply, industrial process and cooling water, waste disposal, and navigation. The other streams in the area are relatively small and generally are dry or nearly so for some part of each year. All are tributary to the Ohio River and rise in narrow valleys in the uplands on either side of the Ohio River. Their channels are tortuous as the streams meander between the hills. Channels generally become wider and the slopes of the streambeds less steep as the streams approach the Ohio River. Perhaps 
the most important feature of these streams is their valleys, which provide favorable sites for municipalities and industry and are used by railroads and highways because of their gentle grades.

The Ohio River is formed by the confluence of the Allegheny and Monongahela Rivers at Pittsburgh. From Pittsburgh the Ohio flows generally southwestward for 981 miles to join the Mississippi River at Cairo, Ill. In volume of flow it is the largest tributary in the Mississippi River system, and it is second only to the Missouri River in size of drainage area.

\section{Records Available}

The U. S. Geological Survey is now operating gaging stations on the Ohio River at Bellaire, Ohio; on Wheeling Creek at Elm Grove, W. Va., ; and on Short Creek near Dillonvale, Ohio. Discharge measurements were made on six other streams in the area and estimates of their flow characteristics were made. Gagingstation sites and measurement sites are shown on plate 1 .

Records of chemical analyses of Ohio River water were obtained from the Wheeling Water Works, at Wheeling; the Weirton Steel Co., at Weirton; and the Beech Bottom Power Co., at Power, W. Va. Samples of water were taken from the eight tributary streams considered in this report. Location of the sampling points and the results of the analyses are shown on plate 1 and table 2 .

\section{Ohio River}

The length of the Ohio River within the area considered by this report is about 40 miles. The drainage area above the gaging station at Bellaire, Ohio, is 25,170 square miles. In the upper Ohio River basin, the Allegheny and Monongahela Rivers rise in the mountainous section that borders the basin to the east. Steep slopes, shallow soils, and heavy precipitation result in high rates of runoff and high water yield. For example, the mean discharge of the Ohio River at Bellaire for the water years 1942-49 was 42 percent of the mean flow for the Missouri River at Hermann, Mo., for the same period.yet the drainage area above Bellaire is only 4.8 percent of that above Hermann.

\section{Navigation}

The Ohio River has been an important factor in the exploration, expansion, and economy of this country. A 9 -foot depth is maintained by a system of locks and dams.

Ohio River locks and dams 10,11, 12, and 13 are within the Wheeling-Steubenville area. Each of these dams has a main lock chamber 600 feet by 110 feet.

\section{Discharge}

The average discharge of the Ohio River at Bellaire, Ohio, for 11 years of record $(1942-52)$ is $27,140 \mathrm{mgd}$ (million gallons per day) or 41,990 cfs (cubic feet per second. The maximum, minimum, and average

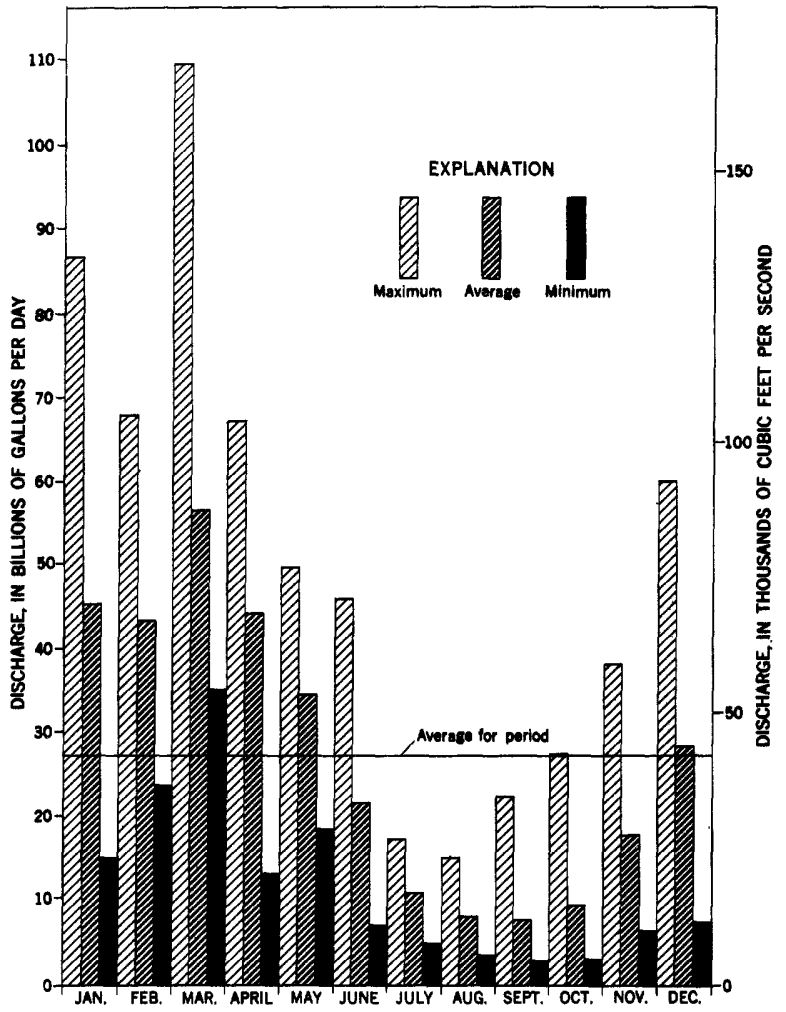

Figure 2. - Maximum, minimum, and average monthly discharge of the Ohio River at Bellaire, 1942-52.

monthly discharges are shown in figure 2. The flow is partially regulated by locks, dams, and reservoirs above the station.

A duration curve of daily flow for the period 1942-52 has been constructed and is shown in figure 3 . This curve shows graphically the characteristics of the river. A flow duration curve showing the streamflow characteristics during the 4-month period July, August, September, and October from October 1941 to September 1952 (water years 1942-52) is also shown in figure 3 . These 4 months were selected as showing the flow characteristics of the river during the part of the year when flows are low and water temperatures are high.

\section{Floods}

The U. S. Corps of Engineers has maintained gages and recorded the stage of the Ohio River at their locks and dams in the vicinity of Wheeling continuously since 1869 and collected fragmentary stage data before that date. The maximum stage of record at lock 12 is 55.2 feet (666. 0 feet above mean sea level) on March 19 , 1936. The tabulation below lists in descending order of magnitude the highest flood stages of record (1869-1952) at lock 12 at Wheeling. Figure 4 shows the recurrence interval in years for floods on the Ohio River at lock 12 at Wheeling. Two curves are shown. The upper curve is for uncontrolled flow, which is the condition existing before construction of any flood-control reservoirs. 


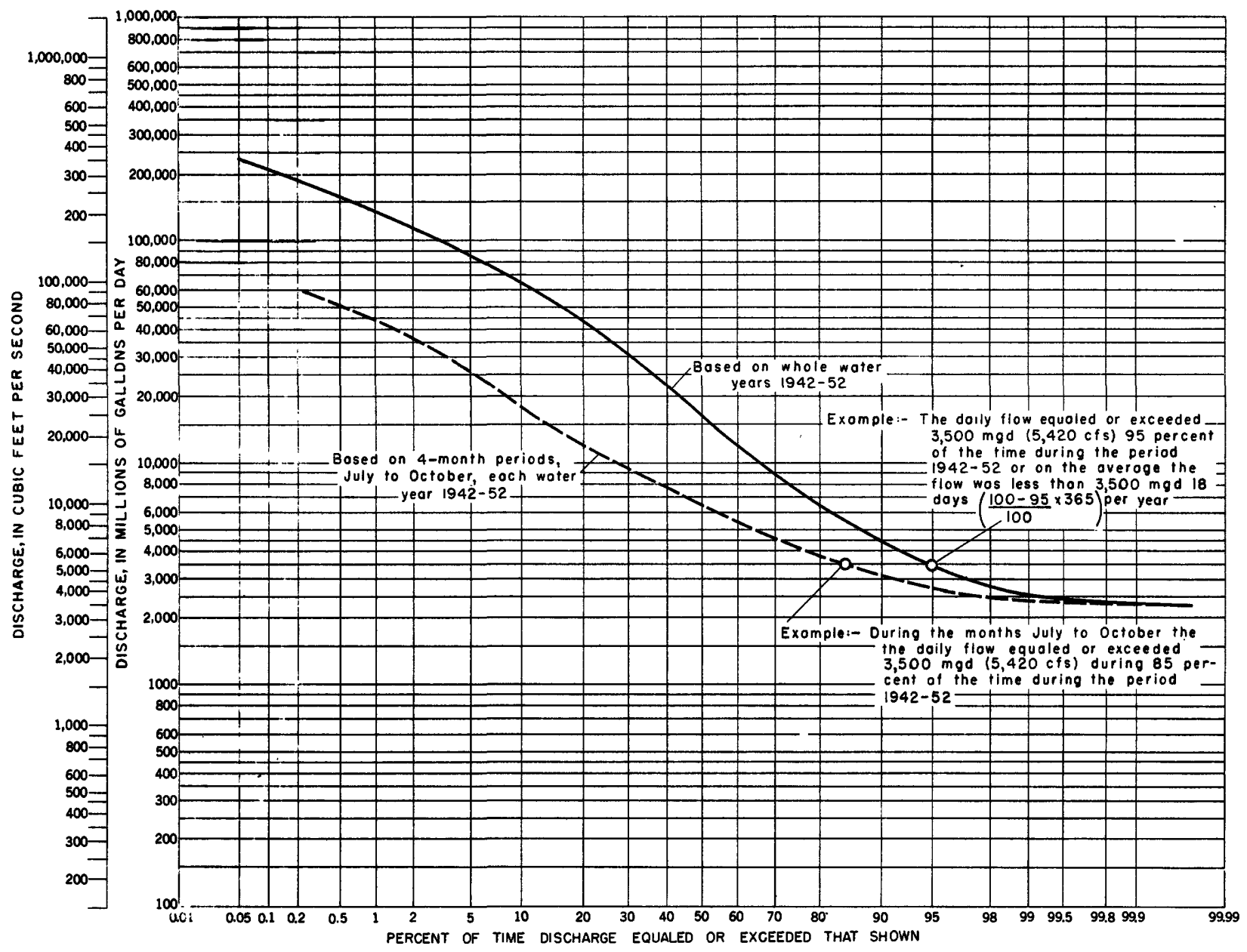

Figure 3. -Duration curve of daily flow, Ohio River at Bellaire, 1942-52.

Major floods on the Ohio River at Wheeling, W. Va., 1869-1952

\begin{tabular}{l|r|r}
\hline \multicolumn{1}{|c|}{ Date } & $\begin{array}{c}\text { Gage height } \\
\text { at lock 12 } \\
\text { (feet) }\end{array}$ & $\begin{array}{c}\text { Altitude above } \\
\text { mean sea level } \\
\text { (feet) }\end{array}$ \\
\hline Mar. 19, 1936 & 55.2 & 666.0 \\
Dec. 31, 1942 & 55.0 & 662.3 \\
Feb. 7, 1884 & 52.8 & 663.4 \\
Mar. 28, 1913 & 52.0 & 662.8 \\
Mar. 15, 1907 & 50.8 & 661.6 \\
Mar. 7, 1945 & 49.6 & 658.1 \\
Apr. 15, 1948 & 48.9 & 655.0 \\
Jan. 26, 1937 & 48.7 & 659.5 \\
Jan. 23, 1937 & 46.2 & 657.0 \\
Apr. 28, 1937 & 45.9 & 656.7 \\
Feb. 18, 1891 & 45.4 & 656.2 \\
Jan. 9, 1913 & 45.4 & 656.2 \\
Mar. 24, 1898 & 45.4 & 656.2 \\
Jan. 23, 1904 & 45.0 & 655.8 \\
\hline
\end{tabular}

Note: Data supplied by the Corps of Engineers, Pittsburgh District.
The lower curve is for flow affected by nine floodcontrol reservoirs: the Tygart, Crooked Creek, Tionesta Creek, Mahoning Creek, Loyalhanna Creek, Youghiogheny, Conemaugh River, Berlin, and Mosquito Creek Reservoirs. Water-surface-profiles of selected floods on the Ohio River between lock and dam 9, above Weirton, W. Va., and lock and dam 14, below Moundsville, W. Va., are given in figure 5 . The frequency of damage by floods in areas along the river may be estimated from figures 4 and 5 . For example, suppose that a manufacturing plant is to be built along the river at mile 100 at Bellaire $(100$ miles downstream from Pittsburgh). The elevation of the plant site is 645 feet above mean sea level, Sandy Hook datum. Assuming that levees are not to be built to protect the site, the frequency of flooding at the plant may be computed as follows: Plot elevation 645 feet at mile 100 (fig. 5). Draw an estimated flood profile that approximately parallels the profile for the February 1948 and April 1948 floods and that passes through elevation 645 at mile 100 . The estimated flood profile shows that a flood whose crest elevation is 645 feet at mile 100 could be expected to have a crest elevation of 652 feet at lock and dam 12. A flood with a crest elevation of 652 at 


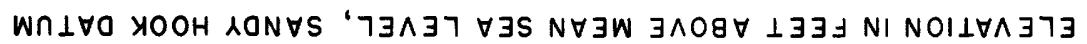

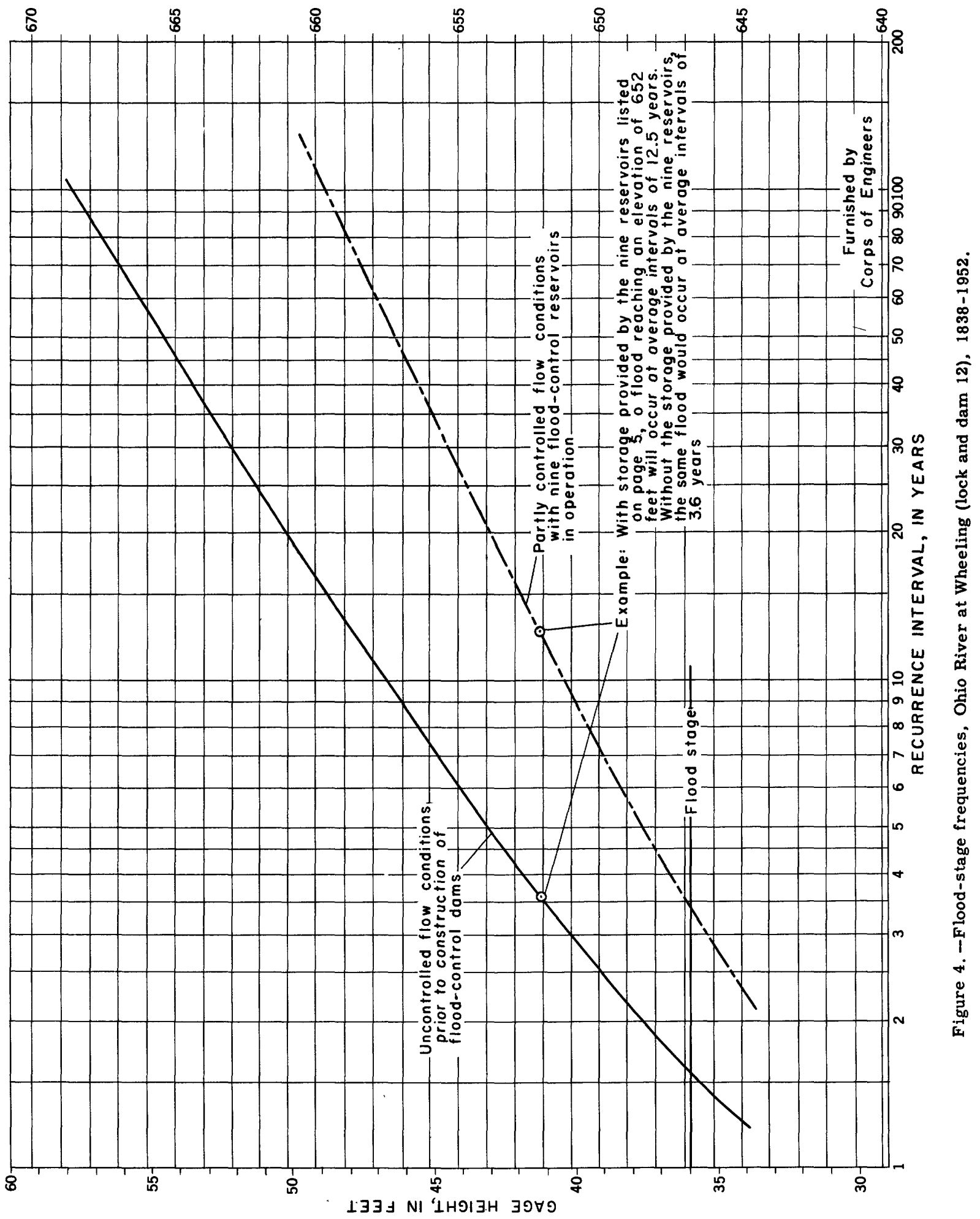


SURFACE WATER

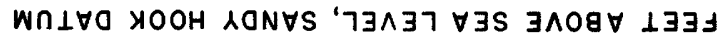

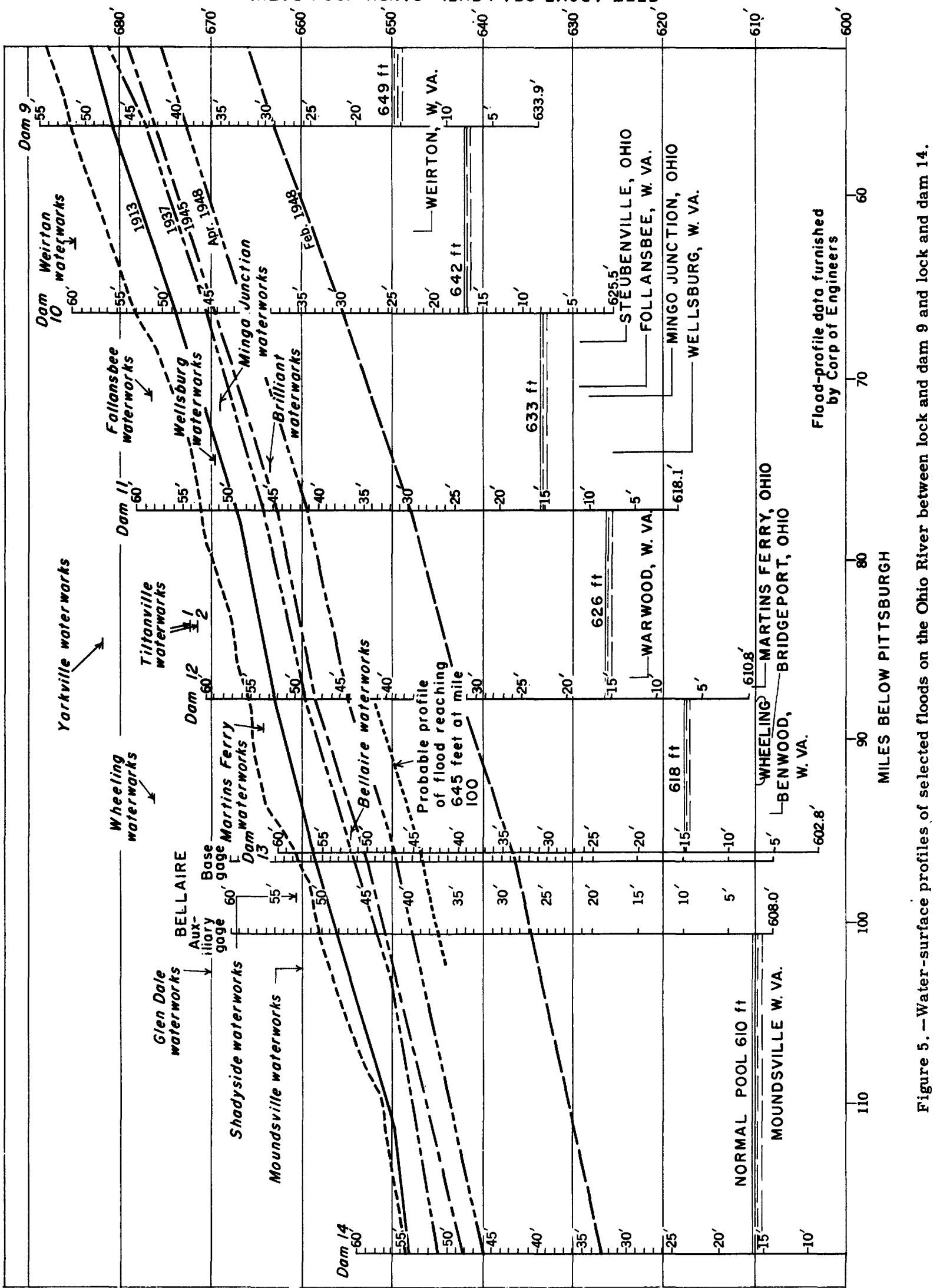


lock and dam 12 has a recurrence interval of $12 \frac{1}{2}$ years (fig. 4). The curve showing present conditions (nine flood-control reservoirs) was used. The plant site will not be flooded at regular intervals of $12 \frac{1}{2}$ years but will be flooded about 10 times in 125 years.

During the period of record, the flood stage of 36 feet at lock and dam 12 has been exceeded 67 times. Floods are most likely to occur during the winter: 37 percent have occurred in March and 78 percent have occurred during January, February, and March. The distribution of floods is shown in figure 6 . The floods of March 19, 1936, and March 28, 1913 inundated practically the entire flood plain of the Ohio River in the Wheeling-Steubenville area.

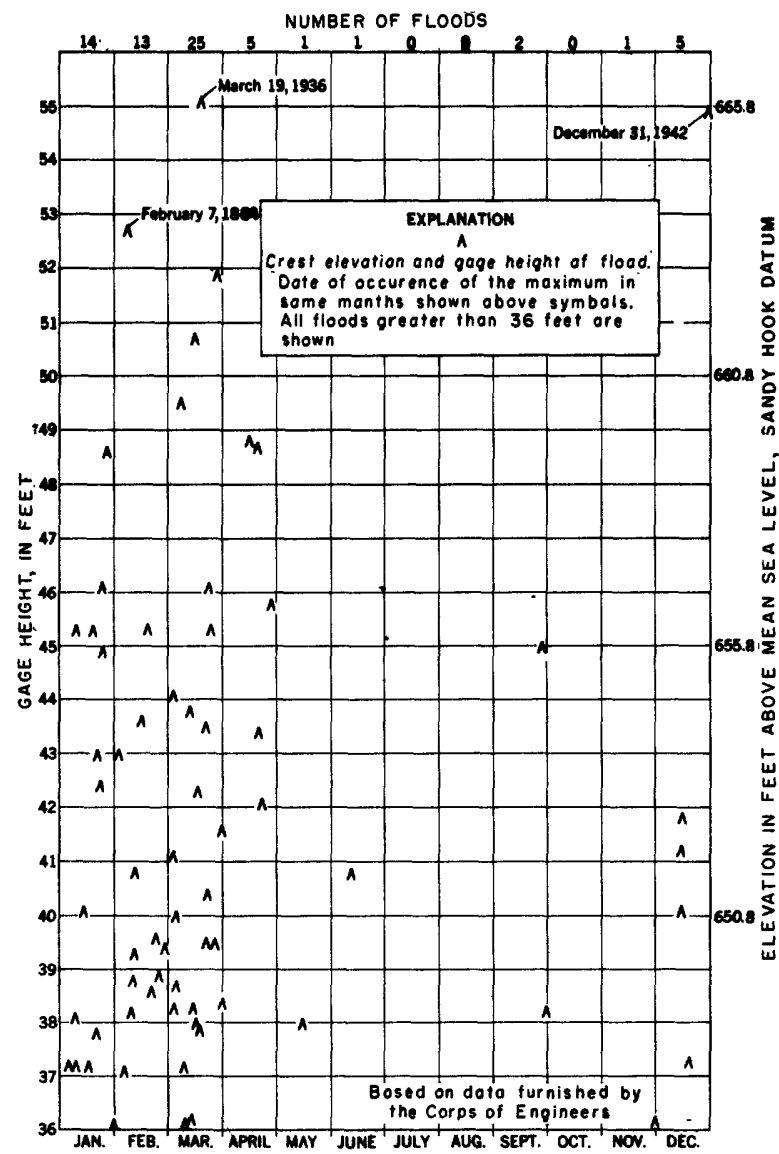

Figure 6. -Frequency of floods by months, Ohio River at Wheeling (lock and dam 12), 1838-1952.

\section{Flood-Control Projects}

The Corps of Engineers has made surveys and plans for local flood protection for the cities and towns along the Ohio River in this area. Agreements have been signed with the cities of Wheeling and Benwood to provide flood-protection works. These projects would be on the West Virginia side of the Ohio River and would comprise an earth levee surmounted by a highway, concrete flood walls, and a cutoff dike. Appropriate facilities would be provided for the disposal of sewage and drainage water from the protected areas during the time of floods, and gates through the protection works would be provided to permit passage of traffic during nonflood periods. Protection would be provided against a flood equal to that of March 1936, the maximum of record.

Surveys and tentative plans for the protection of other municipalities from floods equal in magnitude to the 1936 flood are listed by the Corps of Engineers as "authorized but not started" (1950a, 1950b). Following is a list of the areas considered:
Ohio
W. Va.

Bellaire

Brilliant

Dillonvale

Martins Ferry

Mingo Junction
Follansbee

Moundsville

North Wheeling (Wheeling)

Warwood

Wellsburg

Wheeling Island (Wheeling)
All projects except at Dillonvale would consist of earth levees or concrete walls or both with appropriate facilities for the disposal of sewage and drainage during floods. At Dillonvale the project would consist primarily of deepening, widening, and protecting the channel of Short Creek through the town. A deflection levee and system of drainage ditches would be provided to make the channel improvement fully effective.

The projects would be supplemented by a system of 17 reservoirs on Ohio River tributaries above the project, of which 8 have been completed and 2 were under construction in 1950. The authorized reservoir system would reduce the project-flood crest to an elevation below the top of the protection works. The project flood is defined as the maximum anticipated flood which would be caused by a combination of the severest general storms that have occurred in the various regions of the Ohio River basin.

Operation and maintenance after completion of these projects would be a local responsibility.

\section{Quality}

Continuous daily records of hardness, $\mathrm{pH}$, alkalinity, and temperature maintained since at least 1947 by both the Weirton Steel Co. and the Wheeling Water Works serve as useful indices of the chemical quality of the Ohio River water in the Wheeling-Steubenville area.

Hardness, predominantely noncarbonate, ranged from low to moderate during the period 1948-52: $60-120 \mathrm{ppm}$ (parts per million) as $\mathrm{CaCO}_{3}$ for approximately 50 percent of the time; and it was high, in excess of $200 \mathrm{ppm}$, for about 10 percent of the time (fig. 7). Generally, hardness increased as river discharge decreased (fig. 8). During the period 1948-52, the hardness of the water was highest in September, October, or November, when streamflow was at its lowest. Maximum hardness during 1948-52, $280 \mathrm{ppm}$, was reported at Wheeling on October 8 and 9,1951 . Hardness decreased appreciably during periods of sustained high discharge, which usually occurred in February, March, and April; at Weirton during these months in 1950 , several measurements of 50-60 ppm were recorded. The averages of daily determinations of hardness of Ohio River water at 


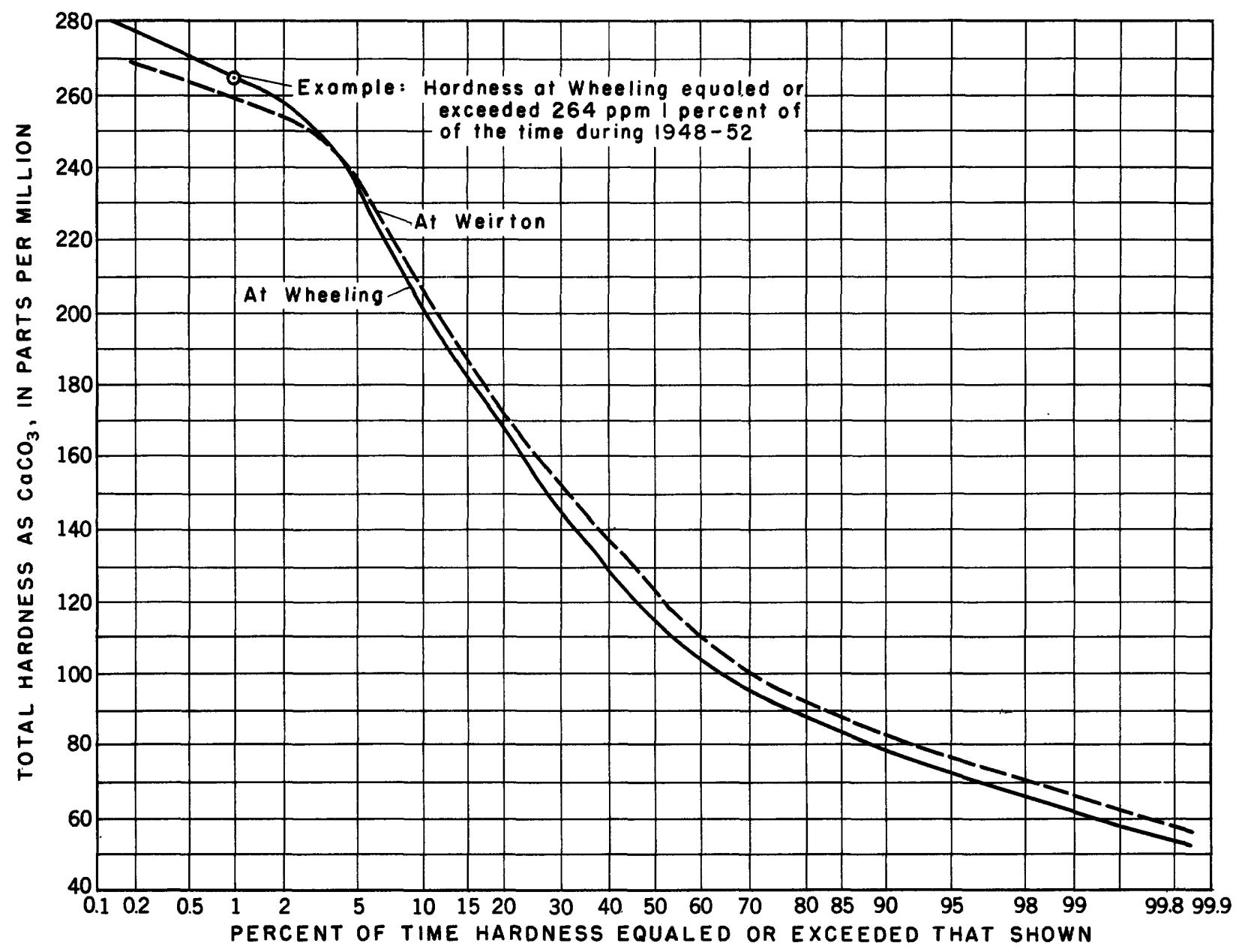

Figure 7. - Cumulative frequency curve of hardness, Ohio River water at Wheeling and Weirton, $1948-52$.

Wheeling reported by the Wheeling Water Works were as follows: 1947, $134 \mathrm{ppm}$; 1948, $109 \mathrm{ppm} ; 1949,123$ ppm; 1950, 114 ppm; 1951, 143 ppm.

Although the $\mathrm{pH}$ of Ohio River water was 7.5 for brief periods during 1947-52, it did not often exceed 7.0. Most of this time the water was only slightly acid, the $\mathrm{pH}$ ranging from 6.0 to 7.0 , but it sometimes remained in the low range of $4.2-5.2$ for several consecutive days. Low $\mathrm{pH}$ readings were observed at Weirton from September 23 to October 13, 1948, and at Wheeling from August 26 to September 2, 1949.

The chemical quality of the Ohio River water, and other surface water in the area, is affected by pollution to the extent that it is unsatisfactory for some uses unless treated. The extent of bacterial pollution is indicated by the coliform count measured in most probable number per 100 milliliters (MPN). In daily samples collected at Short Creek ferry from September 18 to 29,1950 , the count ranged from 2, 400 to 23, $000 \mathrm{MPN}$. The average coliform count was $8,000 \mathrm{MPN}$, which is considerably in excess of the upper limit $(5,000 \mathrm{MPN})$ recommended for public water supplies by the Ohio River Valley Water Sanitary Commission. The invari- ably high sulfate content, which accounts with very few exceptions for 50 percent or more of the dissolved solids (table 1), is indicative of pollution from industrial waste and mine drainage.

A series of 10 measurements of suspended sediment was made by the Corps of Engineers on the Ohio River at Bellaire, Ohio, between July 1942 and May 1945 . These measurements showed that the suspended sediment content varied greatly and in direct relation to the water discharge. The maximum suspended sediment concentration measured was $856 \mathrm{ppm}$ at a discharge of $263,600 \mathrm{cfs}$ and a minimum concentration of $13.3 \mathrm{ppm}$ carried by a discharge of $3,730 \mathrm{cfs}$.

Available data indicate a mean water temperature of $58^{\circ}-59^{\circ} \mathrm{F}$ for the Ohio River in the vicinity of Wheeling and Power during 1948-52 (fig. 9). The mean air temperature in the area is approximately $53^{\circ} \mathrm{F}$. From the middle of November to late in March the temperature of the river was generally within $33^{\circ}$ to $45^{\circ} \mathrm{F}$. At Wheeling in mid-July 1948, and again near the end of August 1950, the temperature of the Ohio River remained at $80^{\circ} \mathrm{F}$ for about 1 week, and it equaled or exceeded $80^{\circ} \mathrm{F}$ during part of June and most of July and August in 1949, 1951, and 1952 . 

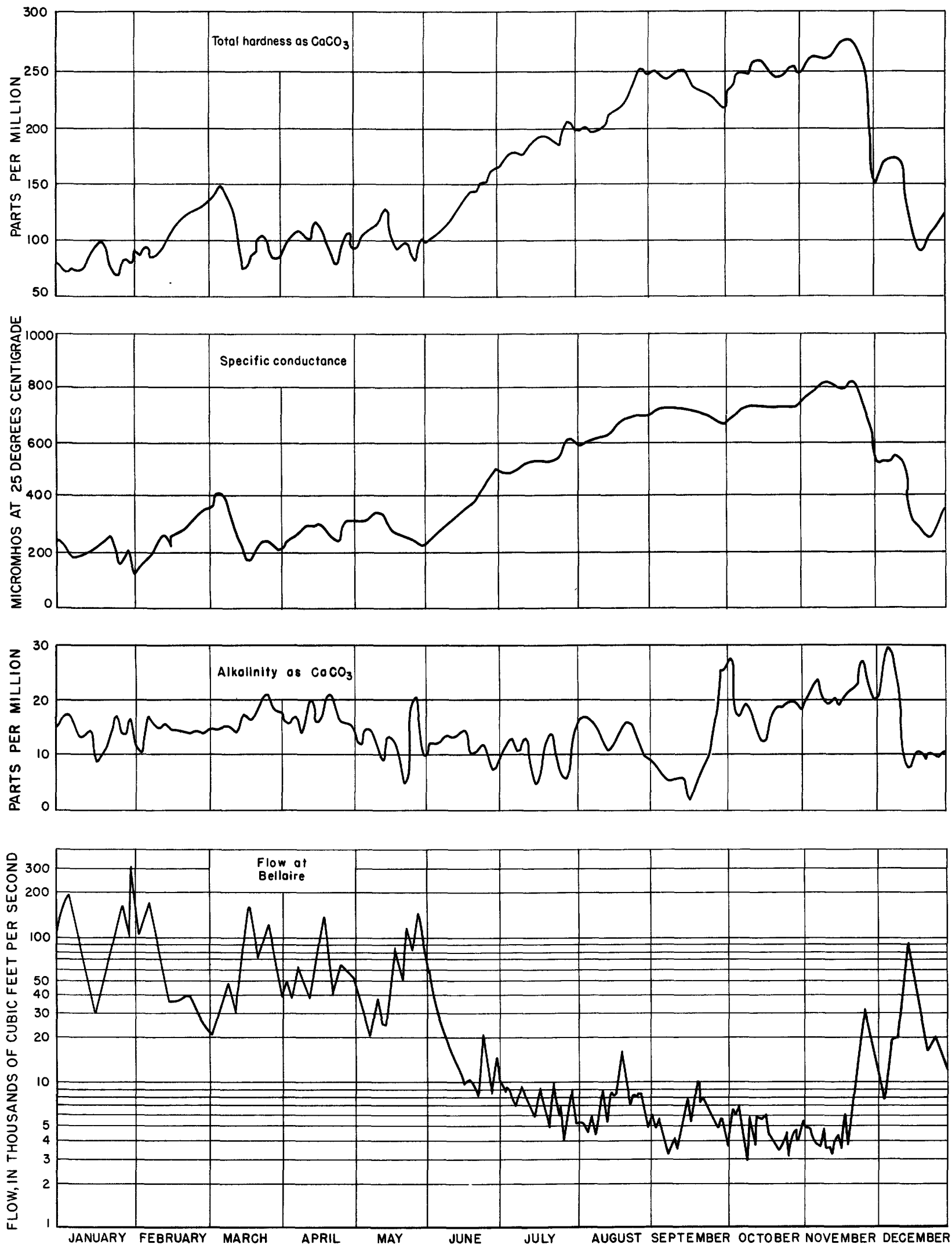

Figure 8. -Relation between streamflow and chemical and physical properties of the water, Ohio River at Power, 1952. 


\begin{tabular}{|c|c|c|}
\hline & 窝 & 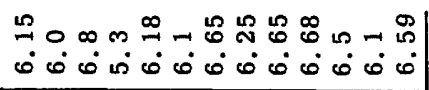 \\
\hline & 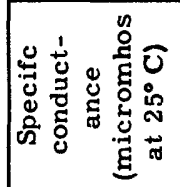 & 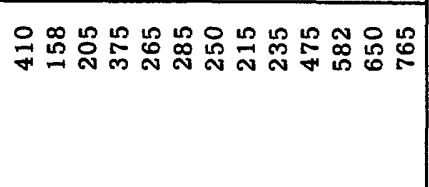 \\
\hline & 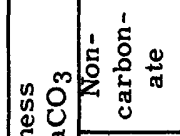 & 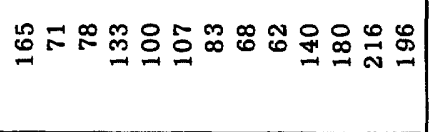 \\
\hline & 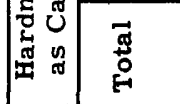 & 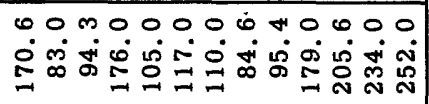 \\
\hline 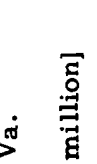 & 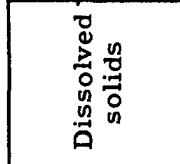 & 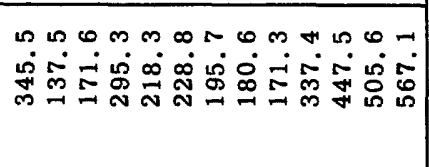 \\
\hline 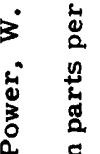 & 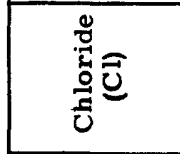 & 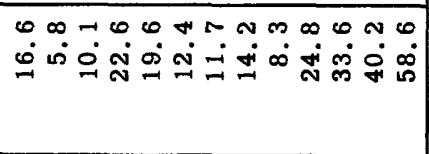 \\
\hline 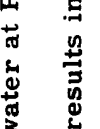 & 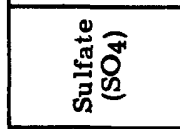 & N \\
\hline ฮี & 密蹗 & 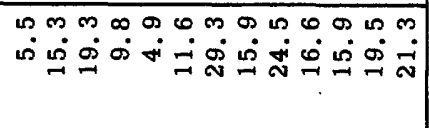 \\
\hline 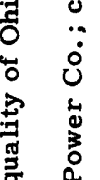 & 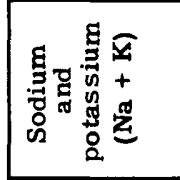 & 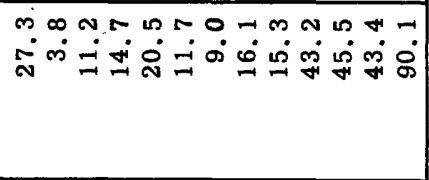 \\
\hline 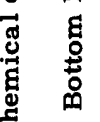 & 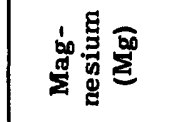 & 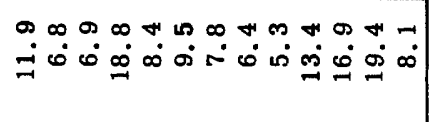 \\
\hline 导 & $\frac{1}{\tilde{\pi}} \tilde{g}$ & 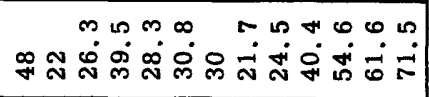 \\
\hline 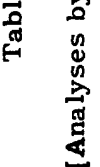 & 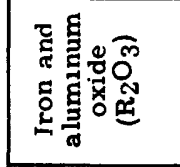 & 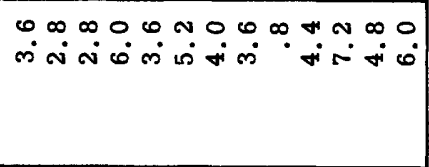 \\
\hline & 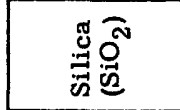 & 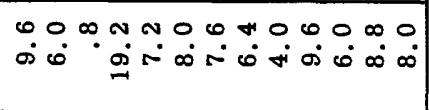 \\
\hline & 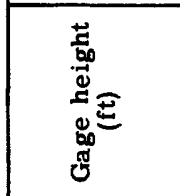 & 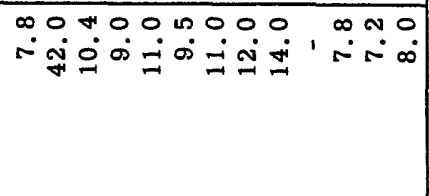 \\
\hline & 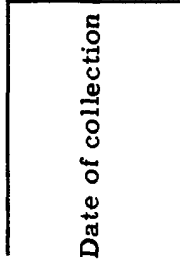 & 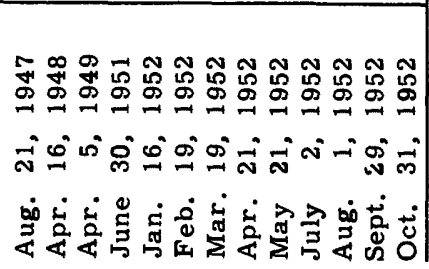 \\
\hline
\end{tabular}




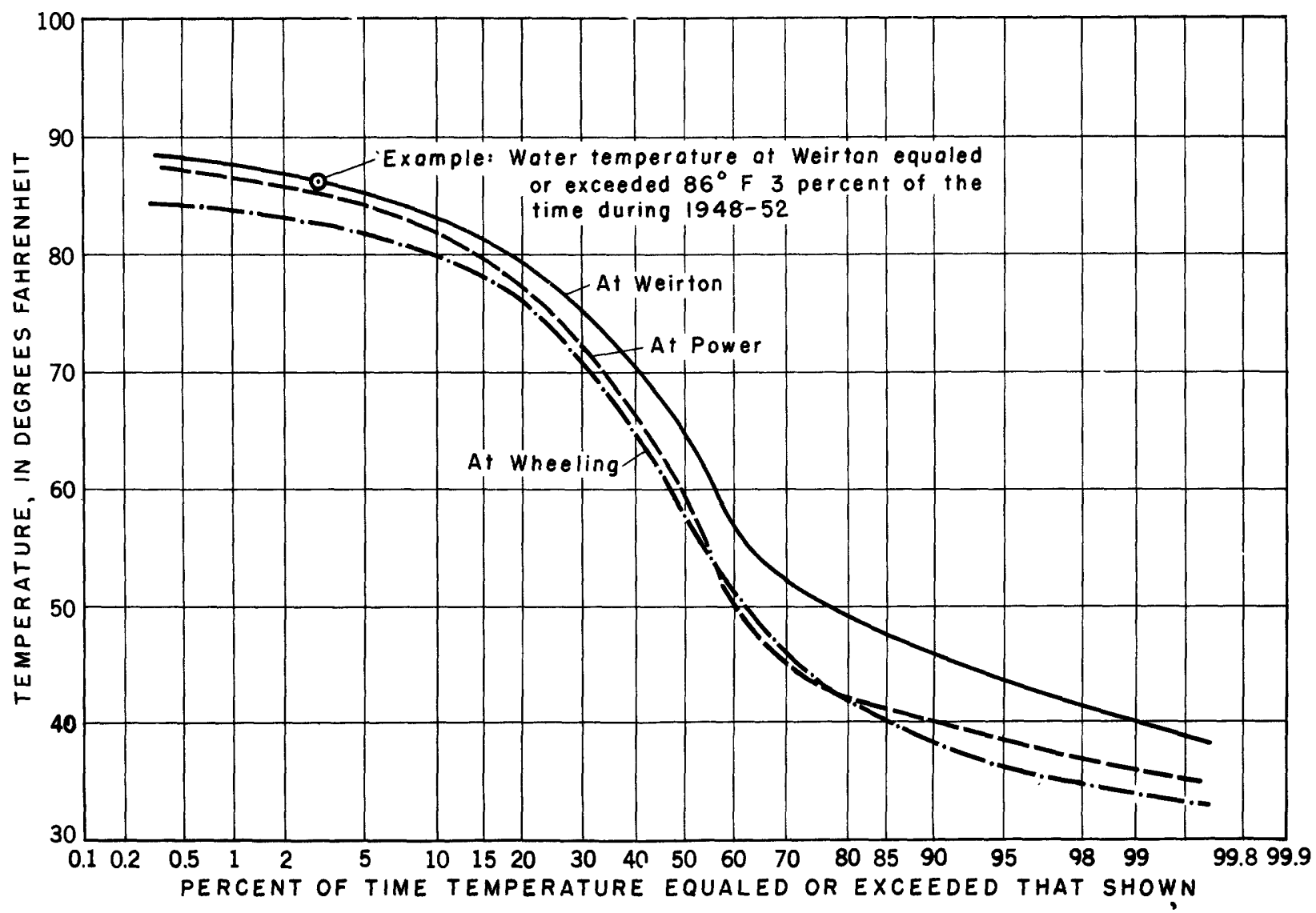

Figure 9. -Cumulative frequency curve of water temperature, Ohio River at Weirton, Power, and Wheeling.

Wheeling Creek at Elm Grove, W. Va.

Wheeling Creek rises in Green and Washington Counties, $\mathrm{Pa}$., at an altitude of 1,500 feet above mean sea level, follows a tortuous route of about 42 miles and empties into the Ohio River at Wheeling, W. Va., at an altitude of 618 feet (pool stage). It flows 13.3 miles in Pennsylvania with an average fall of 46 feet per mile and 28 miles in West Virginia with an average fall of approximately 8 feet per mile. The drainage area is rough throughout, with many steep-sided narrow tributary valleys. The major tributary, with a drainage area of 62 square miles, is Little Wheeling Creek, which enters Wheeling Creek at Elm Grove just upstream from the gaging station. Wheeling Creek drains an area of 298 square miles; of which 160 square miles is in Pennsylvania and 138 square miles is in West Virginia. Streamflow records for 282 square miles of the drainage area have been collected at Elm Grove since November 1940.

\section{Discharge}

The average discharge at Elm Grove for 12 years of record (1941-52) is $218 \mathrm{mgd}$ (338 cfs) or $0.776 \mathrm{mgd}$ per square mile ( $1.20 \mathrm{cfs}$ per square mile). The minimum discharge of record, $0.19 \mathrm{mgd}(0.3 \mathrm{cfs})$, oc-

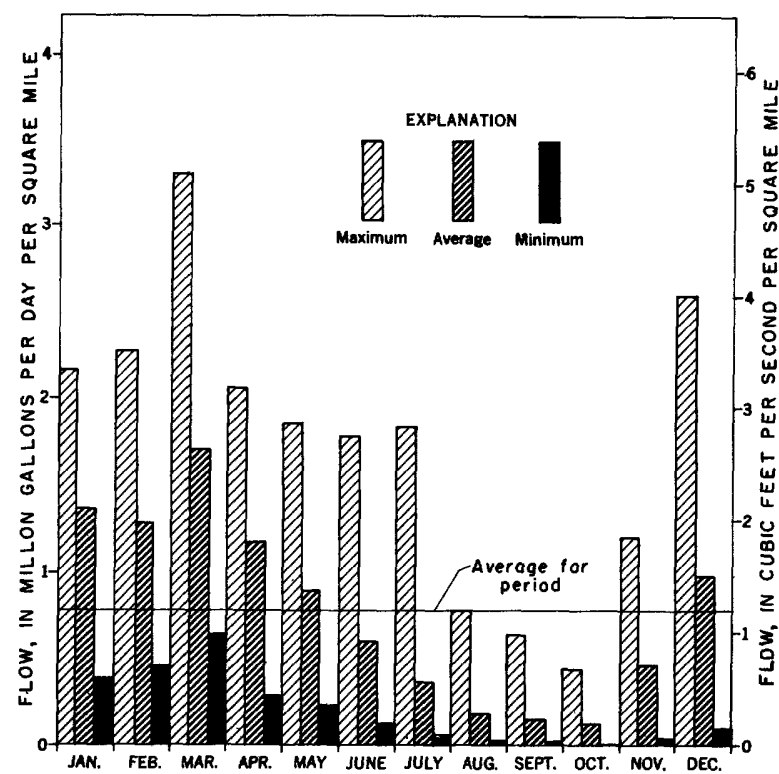

Figure 10. -Maximum, minimum, and average monthly flow Wheeling Creek at Elm Grove, 1941-52. 


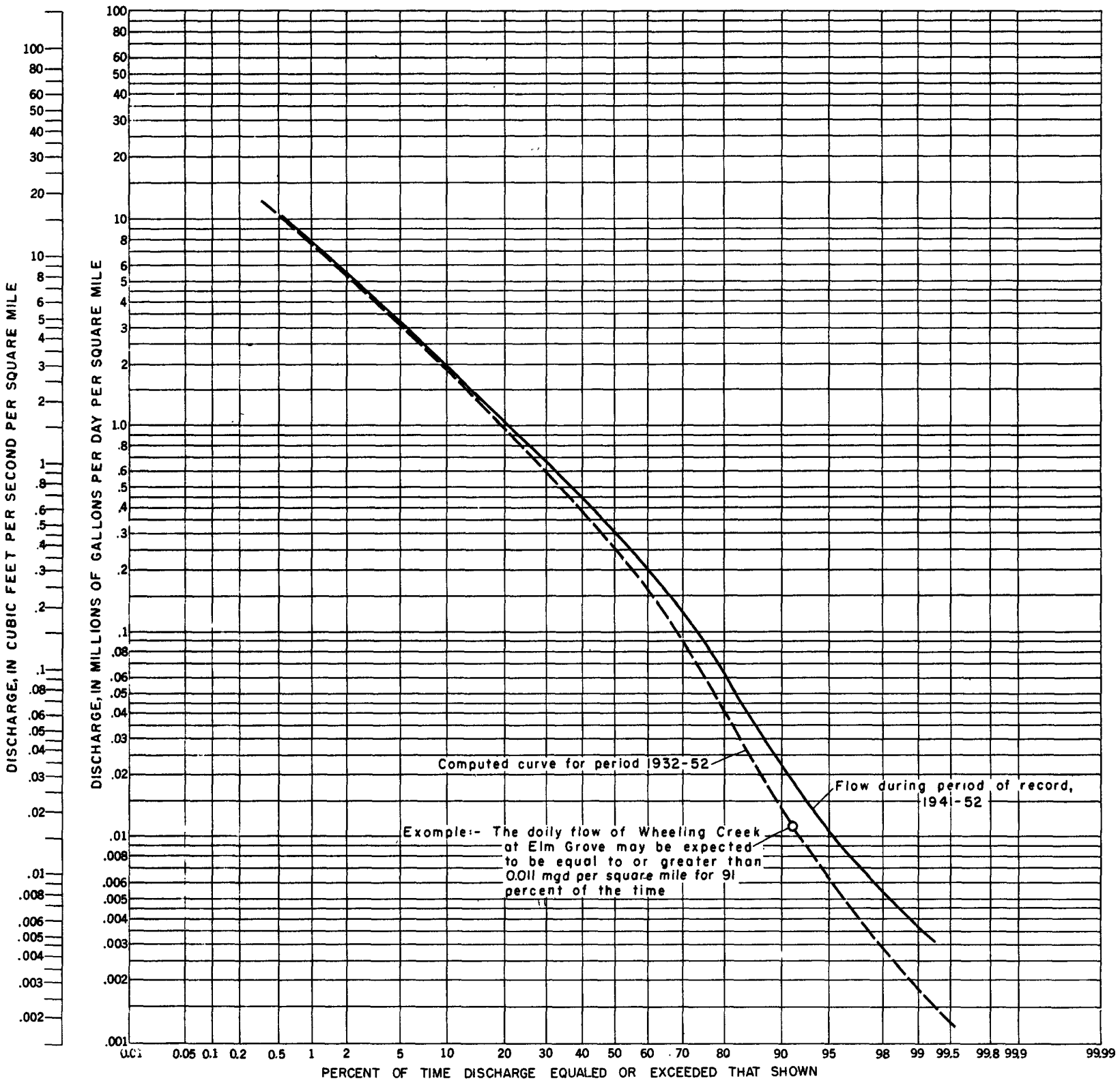

Figure 11. - Duration curve of daily flow, Wheeling Creek at Elm Grove.

curred on September 22, 1949.. Figure 10 shows the maximum, minimum, and average monthly discharge for the period of record. The low-flow characteristics of Wheeling Creek are shown by the flow-duration curve, figure 11 .

The flow-duration curve shows the percentage of time that a specified daily discharge in million gallons per day has been equaled or exceeded. It may be considered a probability curve and used to estimate the probability of occurrence of a specified discharge. It can be used to solve problems of plant location and operation. For example, suppose that it is desired to locate a manufacturing plant on Wheeling Creek near Elm Grove at a place where the drainage area is 280 square miles. Construction of a storage dam is not contemplated. A flow of $3 \mathrm{mgd}$ is required to operate the plant. The average number of days each year that there will be a shortage of water must be known. A flow of $3 \mathrm{mgd}$ at a place where the drainage area is 280 square miles is $0.011 \mathrm{mgd}$ per square mile. The curve for the period October 1932 to September 1952, figure 11, shows that a flow of $0.011 \mathrm{mgd}$ or more is available 91 percent of the time. In an average year there would be sufficient water 332 days and a shortage for $\mathbf{3 3}$ days. The curve for the period 1932-52 was used because this period included extreme droughts and floods and is therefore more representative of the record for a long period than is the record for the period 1941-52. 
Floods

The maximum flood of record on Wheeling Creek was $22,100 \mathrm{cfs}$ on Dec. 30, 1942, at a gage height of 13.67 feet, 681.26 feet above mean sea level (datum of 1929). There is no record of floods that occurred before the beginning of streamflow records in 1941. Peaks above a gage height of 10 feet are listed in the tabulation below.

Major floods on Wheeling Creek at Elm Grove, W. Va.

\begin{tabular}{l|c|r|r}
\hline \multicolumn{1}{c|}{ Date } & Time & $\begin{array}{c}\text { Gage height } \\
\text { (feet) }\end{array}$ & $\begin{array}{c}\text { Discharge } \\
\text { (cfs) }\end{array}$ \\
\hline June 5, 1941 & $2: 30$ a.m. & 13.08 & 17,700 \\
Dec. 30, 1942 & 5:30 a.m. & 13.67 & 22,100 \\
May 31, 1943 & $2: 00$ a.m. & 10.36 & 12,600 \\
July 28, 1943 & $2: 00$ a.m. & - & 18,500 \\
Mar. 6, 1945 & $.6: 00$ p.m. & 12.67 & 19,100 \\
Jan. 15, 1951 & $4: 30$ a.m. & 11.62 & 15,900 \\
\hline
\end{tabular}

\section{Quality}

Five water samples from Wheeling Creek at Elm Grove were collected and analyzed during 1952-53. The samples collected in September and November represent conditions at sustained low flow and those collected in December and February represent conditions at sustained moderate flow. Dissolved solids in the five samples ranged from 187 to $1,196 \mathrm{ppm}$ and hardness ranged from 138 to $490 \mathrm{ppm}$ (table 2). Nitrates ranged from 0.4 to $4.0 \mathrm{ppm}$ when present; one sample had no nitrate. The stream was polluted by domestic and industrial waste and mine drainage.

\section{Short Creek near Dillonvale, Ohio}

Short Creek rises in Harrison County, Ohio, at an altitude of 1,300 feet above mean sea level, flows southeastward, and empties into the Ohio River at Tiltonville, Ohio, at an altitude of 626 feet (pool stage). It flows 11 miles to its junction with North Fork Short Creek, with an average fall of 39 feet per mile, and flows 20 miles from the junction to the mouth, with an average fall of 11 feet per mile. The valleys are wider and the hills are not as rugged as those on the West Virginia side of the Ohio River. Short Creek drains an area of 147 square miles, of which 124 square miles is above the gaging station near Dillonvale.

Table 2. -Chemical quality of water trom selected atreams in the Wheeling-Stenbenville ares

[Chemical result in part per million]

\begin{tabular}{|c|c|c|c|c|c|c|c|c|c|c|c|c|c|c|c|c|c|c|}
\hline \multirow[b]{2}{*}{ Source } & \multirow[b]{2}{*}{$\begin{array}{l}\text { Date of } \\
\text { collection }\end{array}$} & \multirow[b]{2}{*}{$\mid \begin{array}{l}\text { Silica } \\
(\text { SiO) }\end{array}$} & \multirow[b]{2}{*}{$\begin{array}{l}\text { Iron } \\
(\mathrm{Fe}) 1 /\end{array}$} & \multirow[b]{2}{*}{$\begin{array}{l}\text { Cal- } \\
\text { cium } \\
(\mathrm{Ca})\end{array}$} & \multirow[b]{2}{*}{$\begin{array}{c}\text { Mag- } \\
\text { nesium } \\
(\mathrm{Mg})\end{array}$} & \multirow[b]{2}{*}{$\begin{array}{l}\text { So- } \\
\text { dium } \\
(\mathrm{Na})\end{array}$} & \multirow[b]{2}{*}{$\underset{(\mathrm{K})}{\substack{\text { Potes } \\
\text { olum }}}$} & \multirow[b]{2}{*}{$\begin{array}{l}\text { Bleas- } \\
\text { bonate } \\
\left(\mathrm{HCO}_{3}\right)\end{array}$} & \multirow[b]{2}{*}{$\begin{array}{l}\text { Sulfate } \\
\left(\mathrm{SO}_{4}\right)\end{array}$} & \multirow[b]{2}{*}{$\begin{array}{l}\text { Chlo- } \\
\text { idde } \\
\text { (Cl) }\end{array}$} & \multirow[b]{2}{*}{$\begin{array}{c}\text { Fluo- } \\
\text { ride } \\
\text { (F) }\end{array}$} & \multirow[b]{2}{*}{$\begin{array}{l}\mathrm{Ni-} \\
\text { (NO3) }\end{array}$} & \multirow{2}{*}{\begin{tabular}{|l} 
Dissolved \\
sollds \\
(residue \\
on evap- \\
oration \\
at $180^{\circ} \mathrm{C}$ )
\end{tabular}} & \multicolumn{2}{|c|}{$\begin{array}{l}\text { Hardness as } \\
\mathrm{CaCO}_{8}\end{array}$} & \multirow{2}{*}{\begin{tabular}{|l|} 
Specific \\
conduct- \\
ance (mi- \\
cromhos \\
at $25^{\circ} \mathrm{C}$ )
\end{tabular}} & \multirow[b]{2}{*}{$\mathrm{PH}$} & \multirow[b]{2}{*}{ Color } \\
\hline & & & & & & & & & & & & & & $\begin{array}{c}\text { Calcium } \\
\text { mag- } \\
\text { nesium }\end{array}$ & Noncar- & & & \\
\hline \multicolumn{19}{|c|}{ Ohio } \\
\hline $\begin{array}{l}\text { Cross Creek at Mingo } \\
\text { Junction................ }\end{array}$ & $\mid \begin{array}{l}\text { Sept. } 23,1952 \\
\text { Nov. } 25,1952 \\
\text { Dec. } 10,1952 \\
\text { Feb. } 10,1953\end{array}$ & $\begin{array}{l}6.0 \\
6.3 \\
6.2 \\
4.9\end{array}$ & $\begin{array}{l}0.10 \\
.06 \\
.02 \\
.04\end{array}$ & $\begin{array}{l}194 \\
160 \\
132 \\
112\end{array}$ & $\begin{array}{l}43 \\
41 \\
35 \\
30\end{array}$ & \begin{tabular}{|c|}
17 \\
12 \\
7.9 \\
8.3
\end{tabular} & $\begin{array}{l}5.3 \\
3.8 \\
2.3 \\
1.8\end{array}$ & $\begin{array}{r}97 \\
108 \\
68 \\
98\end{array}$ & $\begin{array}{l}609 \\
469 \\
409 \\
326\end{array}$ & $\begin{array}{r}10 \\
9.0 \\
7.0 \\
6.0\end{array}$ & $\begin{array}{r}0.3 \\
.3 \\
.3 \\
.2\end{array}$ & $\begin{array}{r}0.0 \\
.2 \\
.5 \\
.8\end{array}$ & $\begin{array}{r}1,000 \\
808 \\
672 \\
556\end{array}$ & $\begin{array}{l}660 \\
570 \\
475 \\
404\end{array}$ & $\begin{array}{l}581 \\
479 \\
418 \\
322\end{array}$ & $\begin{array}{r}1,230 \\
1,010 \\
860 \\
757\end{array}$ & $\begin{array}{l}7.3 \\
7.6 \\
6.9 \\
7.1\end{array}$ & $\begin{array}{l}3 \\
2 \\
1 \\
5\end{array}$ \\
\hline $\begin{array}{l}\text { Short Creek near } \\
\text { Dillonvale.......... }\end{array}$ & $\mid \begin{array}{l}\text { Sept. } 23,1952 \\
\text { Nov. 25, } 1952 \\
\text { Dec. 10, } 1952 \\
\text { Feb. } 10,1953\end{array}$ & $\begin{array}{l}6.1 \\
6.4 \\
5.3 \\
5.2\end{array}$ & $\begin{array}{l}.04 \\
.03 \\
.04 \\
.02\end{array}$ & $\begin{array}{l}266 \\
264 \\
220 \\
212\end{array}$ & $\begin{array}{l}96 \\
79 \\
61 \\
67\end{array}$ & $\begin{array}{r}140 \\
160 \\
111 \\
68\end{array}$ & $\begin{array}{l}5.9 \\
3.9 \\
4.5 \\
3.4\end{array}$ & $\begin{array}{r}77 \\
65 \\
61 \\
127\end{array}$ & $\begin{array}{r}1,160 \\
1,080 \\
889 \\
787\end{array}$ & $\begin{array}{l}61 \\
84 \\
46 \\
23\end{array}$ & $\begin{array}{l}.4 \\
.5 \\
.3 \\
.4\end{array}$ & $\begin{array}{r}1.0 \\
.7 \\
1.2 \\
1.2\end{array}$ & $\begin{array}{l}2,110 \\
1,830 \\
1,480 \\
1,300\end{array}$ & $\begin{array}{r}1,060 \\
985 \\
800 \\
805\end{array}$ & $\begin{array}{l}995 \\
930 \\
750 \\
700\end{array}$ & $\begin{array}{l}2,220 \\
2,160 \\
1,760 \\
1,570\end{array}$ & $\begin{array}{l}6.1 \\
7.0 \\
6.8 \\
7.3\end{array}$ & $\begin{array}{l}5 \\
4 \\
1 \\
6\end{array}$ \\
\hline ............... & 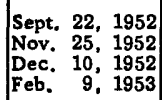 & $\begin{array}{l}7.7 \\
6.5 \\
4.3 \\
5.2\end{array}$ & $\begin{array}{l}.03 \\
.03 \\
.04 \\
.02\end{array}$ & $\begin{array}{l}224 \\
198 \\
164 \\
134\end{array}$ & $\begin{array}{l}58 \\
56 \\
45 \\
40\end{array}$ & $\begin{array}{r}175 \\
169 \\
133 \\
65\end{array}$ & $\begin{array}{l}5.1 \\
3.9 \\
3.7 \\
3.0\end{array}$ & $\begin{array}{r}31 \\
54 \\
46 \\
122\end{array}$ & $\begin{array}{r}1,100 \\
985 \\
793 \\
514\end{array}$ & \begin{tabular}{|c|}
13 \\
12 \\
10 \\
7.0
\end{tabular} & $\begin{array}{r}.5 \\
.5 \\
.3 \\
.3\end{array}$ & $\begin{array}{r}1.7 \\
.8 \\
1.7 \\
1.8\end{array}$ & $\begin{array}{r}1,700 \\
1,530 \\
1,230 \\
881\end{array}$ & $\begin{array}{l}800 \\
725 \\
595 \\
500\end{array}$ & $\begin{array}{l}772 \\
680 \\
557 \\
399\end{array}$ & $\begin{array}{l}2,030 \\
1,850 \\
1,530 \\
1,130\end{array}$ & $\begin{array}{l}7.1 \\
7.0 \\
6.8 \\
7.4\end{array}$ & $\begin{array}{l}3 \\
6 \\
3 \\
5\end{array}$ \\
\hline \multicolumn{19}{|c|}{ West Virginia } \\
\hline $\begin{array}{l}\text { Buffalo Creek at } \\
\text { Wellsburg.............. }\end{array}$ & $\mid \begin{array}{lrl}\text { June } & 9,1952 \\
\text { Sept. } & 22, & 1952 \\
\text { Nov. } & 25, & 1952 \\
\text { Dec. } & 11, & 1952 \\
\text { Feb. } & 10, & 1953\end{array}$ & \begin{tabular}{|c|}
14 \\
4.1 \\
6.9 \\
5.6 \\
4.4
\end{tabular} & $\begin{array}{l}0.11 \\
.07 \\
.03 \\
.24 \\
.18\end{array}$ & $\begin{array}{l}68 \\
91 \\
79 \\
62 \\
04\end{array}$ & $\begin{array}{c}15 \\
21 \\
15 \\
9.2 \\
13\end{array}$ & $\left\{\begin{array}{l}12 \\
29 \\
25 \\
9.2 \\
8.8\end{array}\right.$ & $\begin{array}{l}2.2 \\
.6 \\
6.7 \\
2.6 \\
1.6\end{array}$ & $\begin{array}{l}154 \\
143 \\
150 \\
140 \\
156\end{array}$ & $\begin{array}{r}120 \\
242 \\
144 \\
76 \\
89\end{array}$ & $\begin{array}{c}11 \\
11 \\
25 \\
10 \\
6.0\end{array}$ & $\begin{array}{r}0.0 \\
.2 \\
.2 \\
.2 \\
.2\end{array}$ & $\begin{array}{r}0.2 \\
.6 \\
1.2 \\
2.7 \\
1.9\end{array}$ & $\begin{array}{l}331 \\
488 \\
392 \\
261 \\
271\end{array}$ & $\begin{array}{l}233 \\
316 \\
260 \\
192 \\
212\end{array}$ & $\begin{array}{r}105 \\
196 \\
136 \\
78 \\
85\end{array}$ & $\begin{array}{l}502 \\
720 \\
616 \\
413 \\
434\end{array}$ & $\begin{array}{l}8.1 \\
7.0 \\
8.0 \\
7.3 \\
7.7\end{array}$ & $\begin{array}{r}5 \\
3 \\
8 \\
12 \\
7\end{array}$ \\
\hline Wal & $\begin{array}{ll}\text { Sept. } 22, & 1952 \\
\text { Nov. } 26,1952 \\
\text { Dec. } 11,1952 \\
\text { Feb. } 10,1953\end{array}$ & $\begin{array}{l}6.9 \\
6.8 \\
5.3 \\
5.7\end{array}$ & $\begin{array}{l}.05 \\
.10 \\
.10 \\
.02\end{array}$ & $\begin{array}{r}164 \\
140 \\
69 \\
96\end{array}$ & $\begin{array}{l}49 \\
46 \\
16 \\
28\end{array}$ & $\begin{array}{l}71 \\
68 \\
12 \\
26\end{array}$ & $\begin{array}{l}4.4 \\
4.1 \\
3.9 \\
1.8\end{array}$ & $\begin{array}{r}60 \\
90 \\
96 \\
122\end{array}$ & $\begin{array}{l}667 \\
552 \\
176 \\
293\end{array}$ & \begin{tabular}{c|}
11 \\
12 \\
7.5 \\
5.0
\end{tabular} & $\begin{array}{r}.4 \\
.3 \\
.3 \\
.2\end{array}$ & $\begin{array}{r}.6 \\
1.4 \\
3.8 \\
2.2\end{array}$ & $\begin{array}{r}1,080 \\
926 \\
342 \\
538\end{array}$ & $\begin{array}{l}610 \\
540 \\
238 \\
354\end{array}$ & $\begin{array}{l}562 \\
465 \\
159 \\
255\end{array}$ & $\begin{array}{r}1,340 \\
1,170 \\
520 \\
751\end{array}$ & $\begin{array}{l}7.0 \\
7.7 \\
7.2 \\
7.5\end{array}$ & $\begin{array}{l}5 \\
1 \\
6 \\
1\end{array}$ \\
\hline $\begin{array}{l}\text { Grave Creek near } \\
\text { Moundsville.................... }\end{array}$ & $\begin{array}{l}\text { June } 9,1952 \\
\text { Sept. 24, } 1952 \\
\text { Nov. 26, } 1952 \\
\text { Dec. } 9,1952 \\
\text { Feb. 11, } 1953\end{array}$ & $\begin{array}{c}10 \\
9.6 \\
5.3 \\
4.1 \\
3.8\end{array}$ & $\begin{array}{l}.08 \\
.03 \\
.07 \\
.06 \\
.06\end{array}$ & $\begin{array}{l}45 \\
70 \\
58 \\
49 \\
37\end{array}$ & $\begin{array}{c}8.6 \\
13 \\
9.2 \\
8.3 \\
5.6\end{array}$ & $\begin{array}{l}8.7 \\
46 \\
15 \\
14 \\
5.4\end{array}$ & $\begin{array}{r}2.0 \\
3.8 \\
3.1 \\
1.8 \\
.8\end{array}$ & $\begin{array}{r}133 \\
115 \\
145 \\
116 \\
90\end{array}$ & $\begin{array}{r}46 \\
181 \\
76 \\
73 \\
42\end{array}$ & $\begin{array}{c}11 \\
40 \\
10 \\
10 \\
4.5\end{array}$ & $\begin{array}{l}.0 \\
.2 \\
.1 \\
.1 \\
.1\end{array}$ & $\begin{array}{l}.2 \\
2.7 \\
1.4 \\
2.4 \\
1.7\end{array}$ & $\begin{array}{l}203 \\
436 \\
275 \\
223 \\
146\end{array}$ & $\begin{array}{l}148 \\
228 \\
184 \\
156 \\
115\end{array}$ & $\begin{array}{r}39 \\
134 \\
64 \\
61 \\
42\end{array}$ & $\begin{array}{l}320 \\
679 \\
422 \\
369 \\
267\end{array}$ & $\begin{array}{l}8.0 \\
7.3 \\
7.9 \\
7.7 \\
7.5\end{array}$ & $\begin{array}{r}3 \\
12 \\
4 \\
6 \\
2\end{array}$ \\
\hline $\begin{array}{l}\text { Harmon Creek at State } \\
\text { Highway } 2 \text { at Weirton.... } \\
\text { Harmon Creek at Harmon }\end{array}$ & Sept. 22, 1952 & 10 & $2 / 2.1$ & 79 & 19 & 56 & 5.0 & $3 / 0$ & 368 & 33 & 0.4 & 0.3 & 564 & 275 & 275 & 997 & 3.50 & 6 \\
\hline Creek Road at Weirton... & 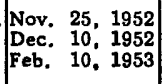 & $\begin{array}{r}11 \\
7.9 \\
8.4\end{array}$ & $\begin{array}{l}4 / .08 \\
5 / .03 \\
6 / .01\end{array}$ & $\begin{array}{l}224 \\
152 \\
152\end{array}$ & $\begin{array}{l}63 \\
43 \\
41\end{array}$ & $\begin{array}{l}23 \\
20 \\
17\end{array}$ & $\begin{array}{l}4.0 \\
4.2 \\
2.6\end{array}$ & $\begin{array}{l}57 \\
60 \\
60\end{array}$ & $\begin{array}{l}785 \\
517 \\
509\end{array}$ & \begin{tabular}{c|}
10 \\
9.5 \\
7.0
\end{tabular} & $\begin{array}{l}.3 \\
.3 \\
.3\end{array}$ & $\begin{array}{r}.3 \\
1.5 \\
1.1\end{array}$ & $\begin{array}{r}1,240 \\
835 \\
812\end{array}$ & $\begin{array}{l}820 \\
555 \\
550\end{array}$ & $\begin{array}{l}771 \\
507 \\
499\end{array}$ & $\begin{array}{l}1,430 \\
1,040 \\
1,020\end{array}$ & $\begin{array}{l}7.1 \\
7.0 \\
7.3\end{array}$ & $\begin{array}{l}4 \\
3 \\
3\end{array}$ \\
\hline e........................... & \begin{tabular}{|lr} 
June & 9,1952 \\
Sept. & 24,1952 \\
Nov. & 26,1952 \\
Dec. & 10,1952 \\
Feb. & 11,1953
\end{tabular} & $\begin{array}{r}11 \\
8.9 \\
8.7 \\
4.7 \\
4.0\end{array}$ & $\begin{array}{l}.06 \\
.15 \\
.04 \\
.09 \\
.04\end{array}$ & $\begin{array}{r}44 \\
144 \\
100 \\
45 \\
54\end{array}$ & $\begin{array}{c}6.8 \\
32 \\
23 \\
8.3 \\
9.2\end{array}$ & $\begin{array}{c}8.3 \\
159 \\
37 \\
7.9 \\
9.3\end{array}$ & $\begin{array}{l}2.2 \\
8.0 \\
3.9 \\
2.6 \\
1.7\end{array}$ & $\begin{array}{r}117 \\
40 \\
29 \\
74 \\
74\end{array}$ & $\begin{array}{r}56 \\
681 \\
354 \\
85 \\
117\end{array}$ & $\begin{array}{c}3.8 \\
91 \\
20 \\
10 \\
5.0\end{array}$ & $\begin{array}{l}.0 \\
.5 \\
.3 \\
.2 \\
.0\end{array}$ & $\begin{array}{r}.4 \\
.0 \\
1.0 \\
4.0 \\
2.3\end{array}$ & $\begin{array}{r}187 \\
1,200 \\
596 \\
212 \\
246\end{array}$ & $\begin{array}{l}138 \\
490 \\
346 \\
146 \\
174\end{array}$ & $\begin{array}{r}42 \\
458 \\
320 \\
85 \\
112\end{array}$ & $\begin{array}{r}318 \\
1,620 \\
810 \\
338 \\
390\end{array}$ & $\begin{array}{l}7.7 \\
5.5 \\
6.3 \\
6.7 \\
7.0\end{array}$ & $\begin{array}{l}5 \\
4 \\
4 \\
6 \\
8\end{array}$ \\
\hline
\end{tabular}




\section{Discharge}

The average discharge near Dillonvale for 11 years of record (1942-52) is $92 \mathrm{mgd}(142 \mathrm{cfs}$ ) or $0.74 \mathrm{mgd}$ per square mile (1.15 cfs per square mile). The minimum discharge of record is $1.8 \mathrm{mgd}(2.8 \mathrm{cfs})$ and occurred on September 21, 1947. The maximum, minimum, and average monthly discharge for the period of record are shown in figure 12. The low-flow characteristics of Short Creek are shown by the flow-duration curves, figure 13. One curve is for the period of record, 1942-52. The other curve, for the period October 1932 to September 1952, was computed by correlation with records of South Fork Tenmile Creek at Jefferson, $\mathrm{Pa}$. and Little Beaver Creek near East Liverpool, Ohio. The curve for the period 1932-52 should be used for planning because this period included extreme droughts and floods and is therefore more representative of the flow during a long period.

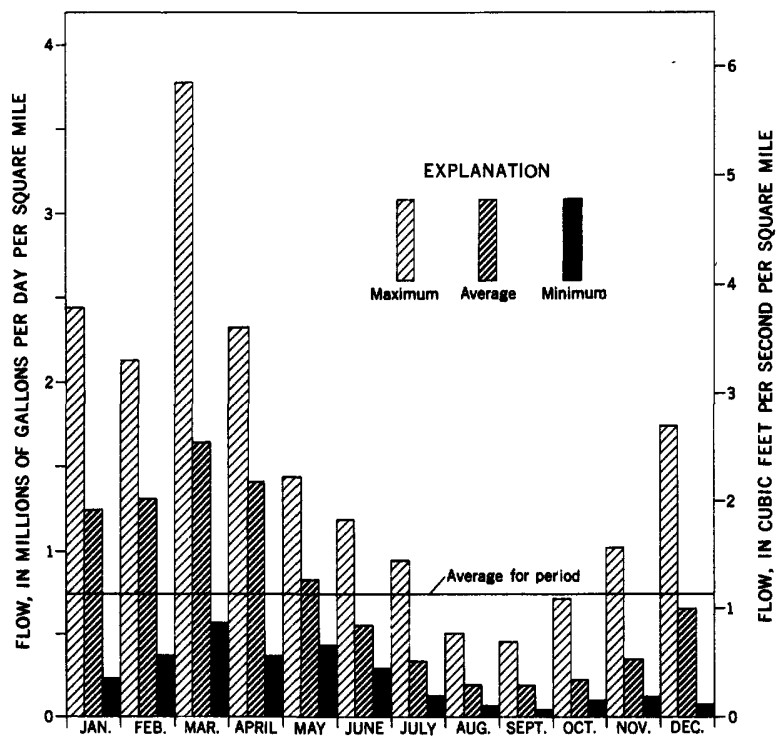

Figure 12.--Maximum, minimum, and average monthly flow, Short Creek near Dillonvale, Ohio, $1941-52$.

\section{Floods}

The maximum flood of record on Short Creek was $6,500 \mathrm{cfs}$ on March 6, 1945, at a gage height of 8.77 feet, 684.87 feet above mean sea level. There is no record of floods that occurred before the beginning of streamflow records in 1942 .

\section{Quality}

Four water samples from Short Creek near Dillonvale were collected and analyzed during 1952-53. The samples collected in September and November represent conditions at sustained low flow and those collect-

ed in December and February represent conditions at sustained moderate flow. The dissolved-solids content of Short Creek waters was higher than any other surface water sampled (table 2). Sulfate accounted for more than 50 percent by weight of the dissolved solids, and sulfate and calcium together accounted for more than 65 percent by weight of the dissolved solids. It is not economically feasible to treat this water for use for boiler feed or for most industrial and domestic uses. Mine and domestic wastes are the principal pollutants. The stream carries large amounts of suspended coal dust.

\section{Other Streams}

In addition to the gaging stations on Wheeling Creek at Elm Grove and Short Creek near Dillonvale, investigations were made on six other streams. They are directly tributary to the Ohio River in downstream order as follows: Harmon Creek at Weirton, W. Va.; Cross Creek at Mingo Junction, Ohio; Cross Creek near Wellsburg, W. Va.; Buffalo Creek at Wellsburg, W. $\mathrm{Va}$.; Wheeling Creek at Bridgeport, Ohio; and Grave Creek at Moundsville, W. Va. (See plate 1.) Drainage areas are given in the tabulation below. Discharge measurements were made at medium and low flows at selected sites on these six streams. The probable lowflow characteristics of these streams were then computed by correlating the discharge measurements with continuous discharge records for gaging stations within the Wheeling-Steubenville area and also with records for gaging stations on South Fork Tenmile Creek at

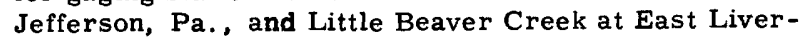
pool, Ohio.

Drainage areas of small streams in the WheelingSteubenville area

$$
\begin{aligned}
& \text { Drainage } \\
& \text { area }
\end{aligned}
$$
(sq $\mathrm{mi}$ )
Stream

\section{Remarks}

Ohio:

$\begin{array}{lrc}\text { Cross Creek } & 128 & \text { At measuring point. } \\ \text { Wheeling Creek } & 108 & \text { Do. } \\ \text { West Virginia: } & & \\ \text { Buffalo Creek } & 162 & \\ \text { Cross Creek } & 76 & \text { Do. } \\ \text { Grave Creek } & 75 & \\ \text { Harmon Creek } & 69 & \end{array}$

Four samples of water from each of the six streams were collected and analyzed during 1952-53. The samples collected in September and November represent conditions at sustained low flow, and those collected in December and February represent conditions during sustained moderate flow. The mineral content of these streams differed widely (fig. 14). Wheeling Creek (in Ohio) contained such high concentrations of dissolved mineral substances, particularly calcium, magnesium, and sulfate, that it would be an unsatisfactory source of water for many industrial and domestic uses. Grave and Buffalo Creeks contained only moderate concentrations of dissolved minerals. Table 2 lists the analyses of the waters from the small streams in the area. 


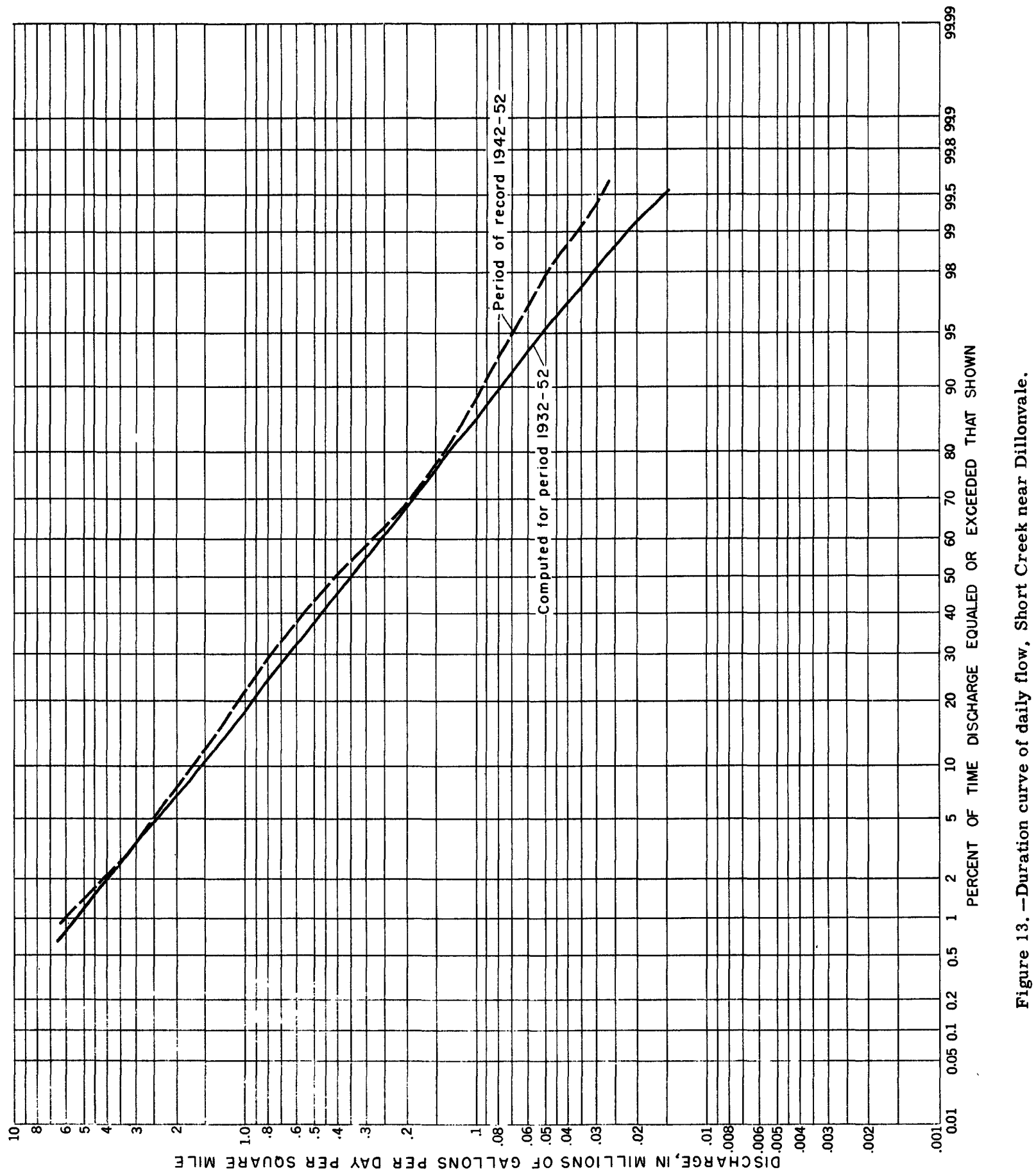

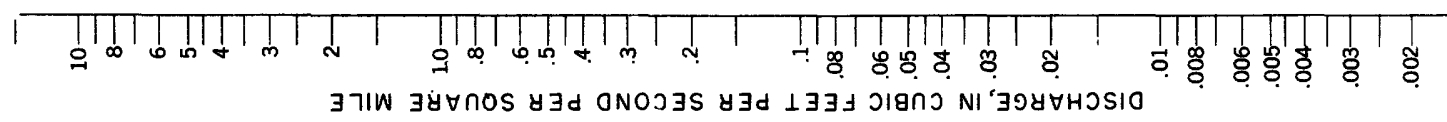




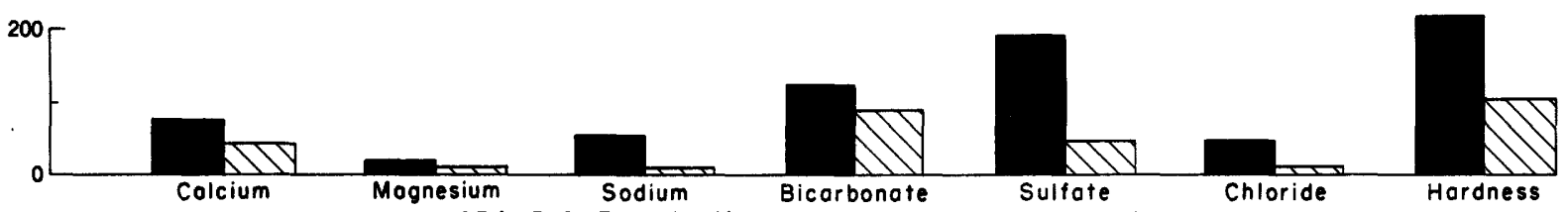

GRAVE CREEK AT MOUNDSVILLE, WEST VIRGINIA

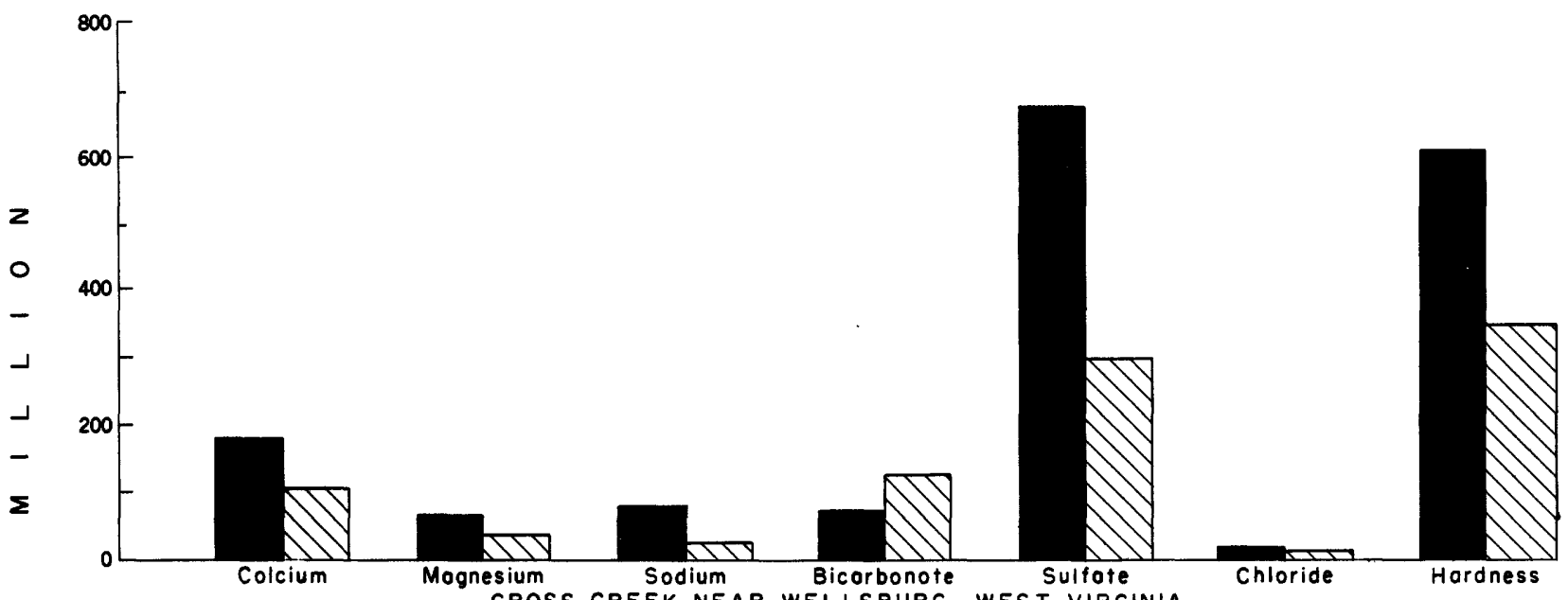

$\simeq$

w

$a$

$\infty$

$\vdash$

జ

$\varangle$

0
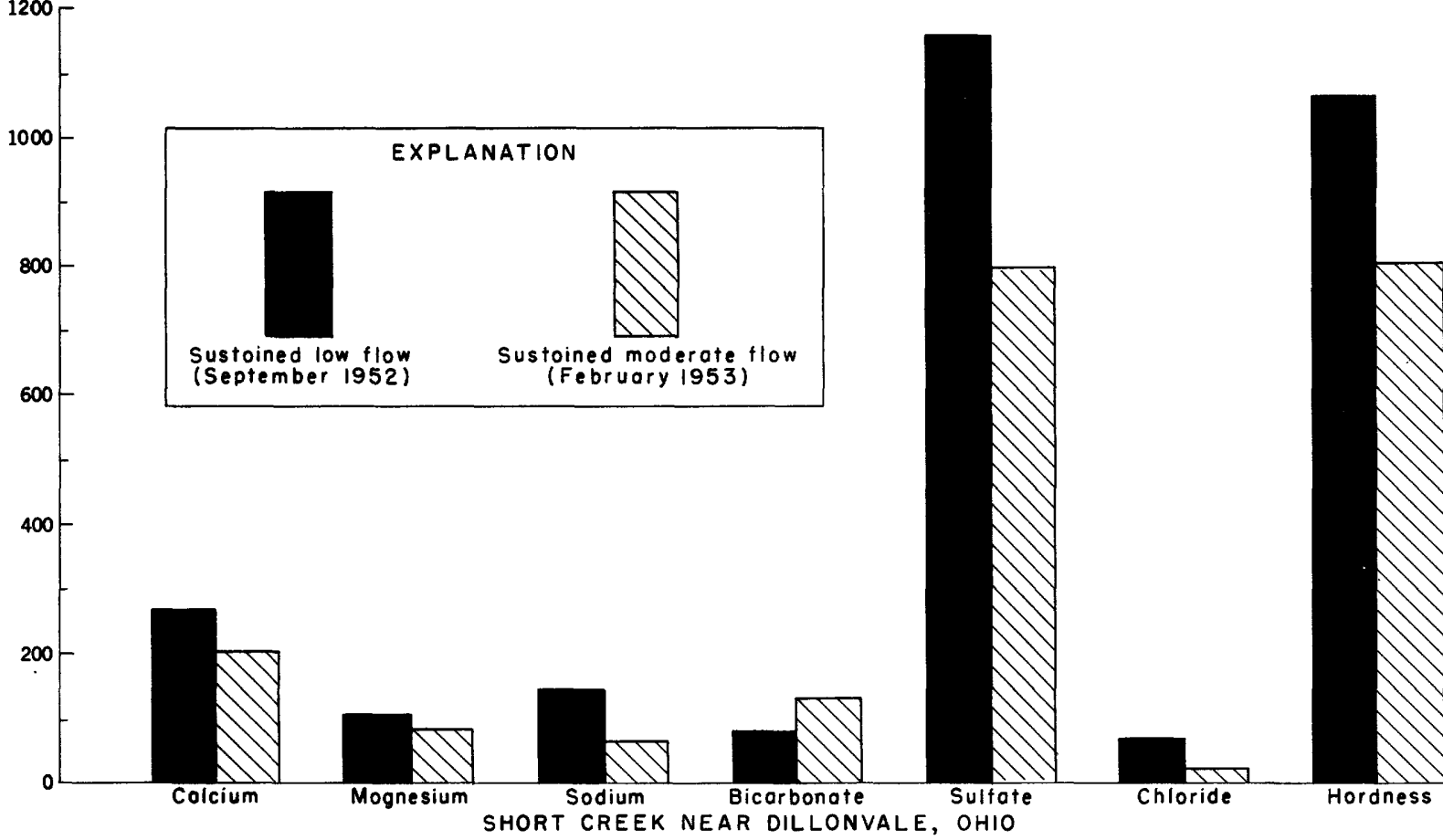

Figure 14. - Chemical quality of water from selected small streams. 
Harmon Creek at Weirton, W. Va.

Three of the discharge measurements made during 1952 and 1953 were made below the Weirton Steel Mill and contain process water, therefore they do not reflect the natural discharge of this stream. The drainage area at the point of measurement is 65 square miles. No data concerning floods at this site are available. The minimum discharge measured was $5.99 \mathrm{mgd}$ or $9.27 \mathrm{cfs}$.

The dissolved-solids content in four samples of water from Harmon Creek consisted largely of calcium, magnesium, and sulfate and ranged from 564 to 1,240 ppm. Hardness of Harmon Creek water was high, 275 to $820 \mathrm{ppm}$, and was largely noncarbonate (table 2). The samples collected above Weirton contained only small amounts of dissolved iron, but the amount of iron in sediment ranged from 2.6 to $69 \mathrm{ppm}$. Dissolved manganese ranged from 1.4 to $3.6 \mathrm{ppm}$. The stream was polluted by mine drainage and domestic waste.

\section{Cross Creek at Mingo Junction, Ohio}

Eight discharge measurements were made during 1950,1952 , and 1953. The drainage area at the point of measurement is 128 square miles. The minimum discharge measured was $6.85 \mathrm{mgd}$ or $10.6 \mathrm{cfs}$. The computed duration curve for the period $1932-52$ is shown in figure 15.
Four samples collected from Cross Creek at Mingo Junction, Ohio, contained between 556 and $1,000 \mathrm{ppm}$ of dissolved solids. Calcium, magnesium, and sulfate collectively accounted for most of the dissolved solids. Hardness of Cross Creek water was high, 404 to 660 ppm, and principally noncarbonate (table 2).

\section{Cross Creek Near Wellsburg, W. Va.}

Six discharge measurements were made during 1952 and 1953. The drainage area at the point of measurement is 76 square miles. No data concerning floods at this site are available. The minimum discharge measured was $4.40 \mathrm{mgd}$ or $6.81 \mathrm{cfs}$. A computed duration curve of daily flow for the period 1932-52 is shown in figure 15.

Four samples of water from Cross Creek near Wellsburg contained between 342 and $1,080 \mathrm{ppm}$ of dissolved solids. Calcium, magnesium, sodium, and sulfate accounted for most of the mineral constituents. Nitrate content ranged from 0.6 to $3.8 \mathrm{ppm}$. These waters were hard, ranging from 238 to $610 \mathrm{ppm}$ hardness; most of this hardness was noncarbonate (table 2).

Buffalo Creek at Wellsburg, W. Va.

Ten discharge measurements were made during 1950 , 1952, and 1953. The drainage area at the point of meas -

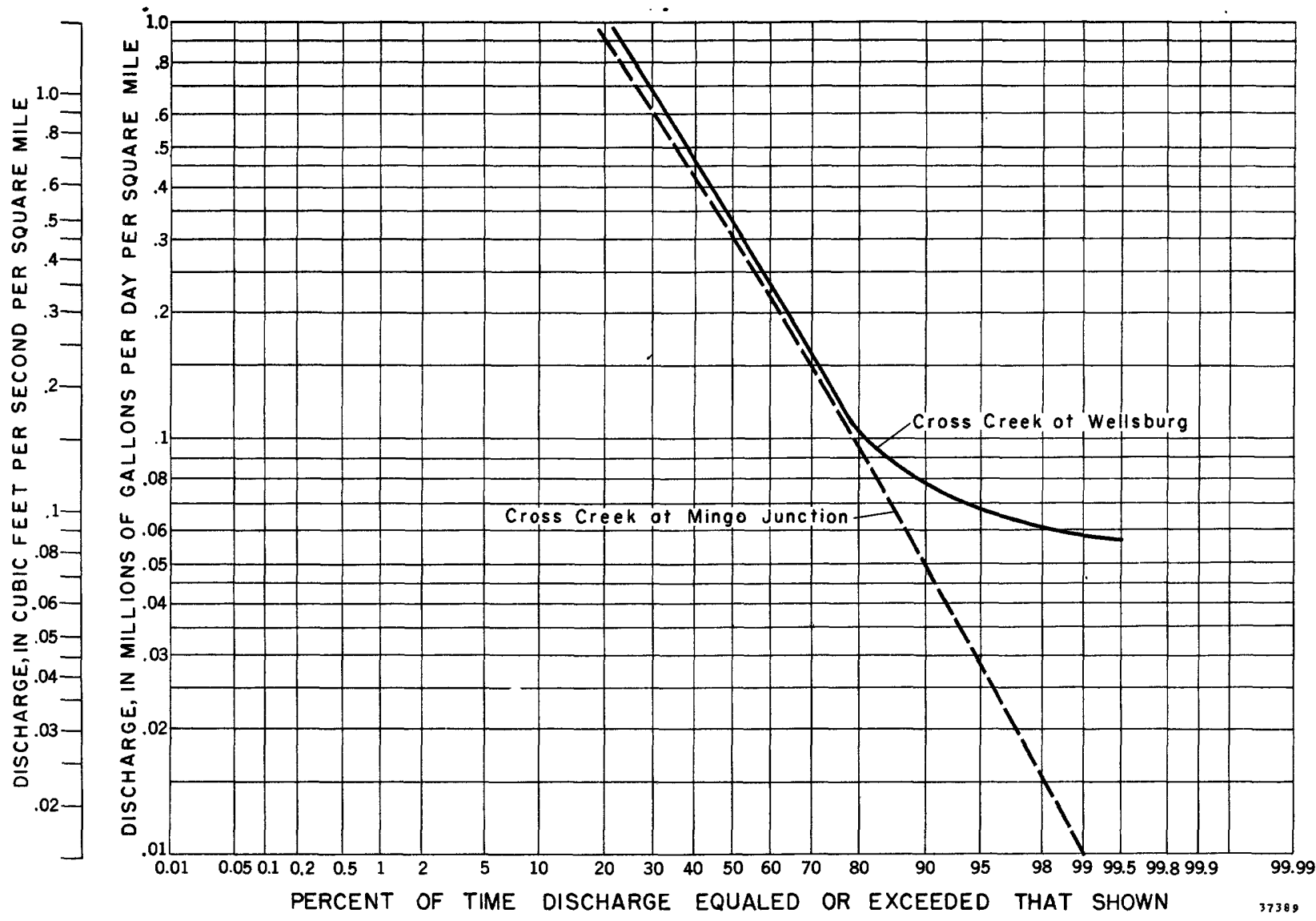

Figure 15. - Computed duration curve of daily flow, Cross Creek at Mingo Junction, Ohio, and Cross Creek at Wellsburg, W. Va., 1932-52. 


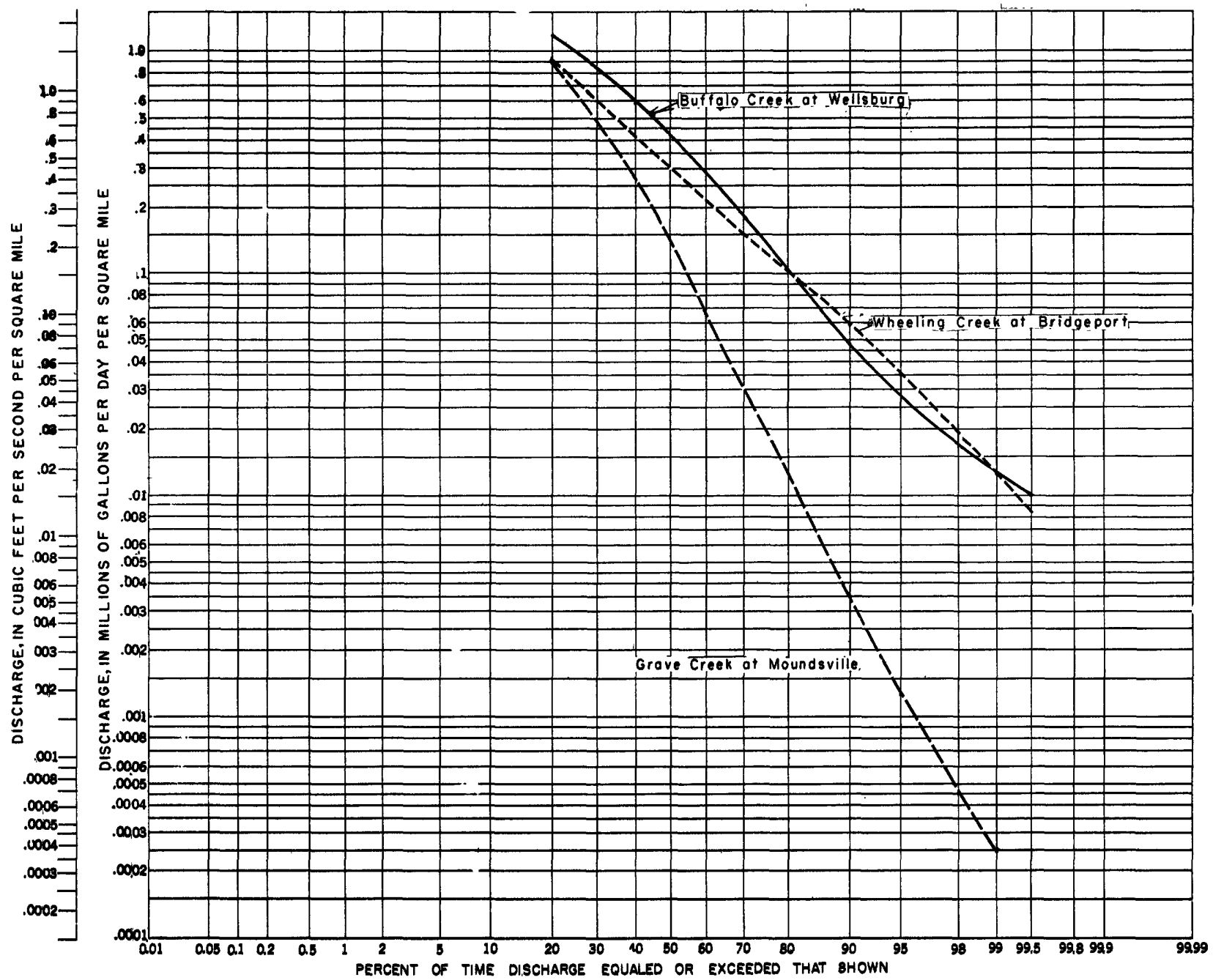

Figure 16, -Computed duration curve of daily flow, Buffalo Creek at Wellsburg, W. Va.; Wheeling Creek at Bridgeport, Ohio; and Grave Creek at Moundsville, W. Va. ; 1932-52.

urement is 161 square miles. No data concerning floods at this site are available. The minimum discharge measured was $2.22 \mathrm{mgd}$ or $3.44 \mathrm{cfs}$. The computed duration curve of daily flow for the period 193252 is shown in figure 16.

The water of Buffalo Creek was lower in mineral content and hardness than most of the other surface waters in the area. Dissolved solids in five samples ranged from 261 to $488 \mathrm{ppm}$. Hardness ranged from 192 to $316 \mathrm{ppm}$ (table 2). Four of the five samples collected contained more bicarbonate than sulfate.

\section{Wheeling Creek at Bridgeport, Ohio}

Eight discharge measurements were made during 1950,1952 , and 1953. The drainage area at the point of measurement is 108 square miles. No data concerning floods at this site are available, although according to the Corps of Engineers, Cincinnati, Ohio, five floods on the Ohio River-1913,1936, 1937, 1945 and 1948-exceeded the height of the highway bridge at Bridgeport. The minimum discharge measured was $6.72 \mathrm{mgd}$ or $10.4 \mathrm{cfs}$ on Oct. 28, 1952. A computed duration curve of daily flow for the period 1932-1952 is shown in figure 16 .

Dissolved solids in four water samples from Wheeling Creek at Bridgeport, Ohio, ranged from 881 to 1,700 ppm. Calcium, sodium, and sulfate were the principal constituents. These waters were very hard, ranging from 500 to $800 \mathrm{ppm}$ hardness (table 2). This water, like that of Short Creek, contains more calcium and sulfate than is tolerable for some industrial and domestic uses. The stream was polluted by domestic waste and mine drainage:

Grave Creek at Moundsville, W. Va.

Nine discharge measurements were made during 1950 and 1952. The discharge at Moundsville was computed 
by totaling the discharge of Middle Grave Creek and Grave Creek above Middle Grave Creek. The combined drainage area is 74 square miles. No data concerning floods at these sites are available. The minimum combined discharge measured was $0.039 \mathrm{mgd}$ or $0.06 \mathrm{cfs}$. The computed duration curve of daily discharge for the period 1932-52 is shown in figure 16 .

The observed mineral content of the water in five samples from Grave Creek above Moundsville was generally lower than that of any other small streams that were sampled. Dissolved solids ranged from 146 to $436 \mathrm{ppm}$. Hardness, which ranged from 115 to $228 \mathrm{ppm}$, was the lowest for all small streams sampled (table 2). This stream receives some mine drainage and domestic waste from a thinly populated area, but it is one of the less polluted streams in the area.

\section{GROUND WATER}

Water occurs beneath the surface of the earth in the minute pores and the cracks and crevices that are present in the rocks. The amount of ground water available in any area depends on the number, kind, and size of the water-bearing openings in the rock. Permeability is the ability of a water-bearing formation to transmit water and is dependent upon the size, number, and interconnection of the openings in the formation. Generally, unconsolidated deposits of sand and gravel are the most permeable formations, and shale and clay or silt are the least permeable.

The amount of ground water continuously available in any area is also determined by the amount of recharge available and the distance to that recharge. Although water can be withdrawn for a time from storage in the formation, it is obvious that once the storage is exhausted no more water can be withdrawn than is replenished through recharge.

\section{Geology and Water-Bearing Properties of the Consolidated and Unconsolidated Deposits}

The rocks of the Wheeling-Steubenville area are of two major types: consolidated sedimentary layers of Carboniferous age and unconsolidated deposits of Pleistocene and Recent age. The unconsolidated Pleistocene deposits occur only in the valley of the Ohio River and near the mouths of some of the tributary valleys and are the more important of the deposits with respect to the availability of ground-water supplies. The deposits of Recent age are generally silt and fine sand deposited by the Ohio River and the larger tributaries on their flood plains. The consolidated rocks underlie the Pleistocene and Recent deposits and crop out over the remainder of the area.

\section{Consolidated Formations}

The consolidated rocks of the area consist of sandstone, shale, limestone, coal, and clay. The rock layers are extremely variable in composition and thickness: massive sandstones grade into sandy, thinbedded shales within a few hundred feet, and limestones occur in thin patches. There is no important water-bearing formation, primarily because the formations are not extensive laterally.
Ground water in the consolidated rocks of the Wheeling-Steubenville area generally occurs in the cracks and crevices in the rock rather than in the pores of the rock, and in many places the shales are more productive than the sandstones. The topography affects the ground-water conditions more than does the mineral nature of the rock. The most productive wells are in the valleys where they tap the water-bearing formations below the adjacent streams. Some water can generally be obtained from hilltop wells, but these are apt to dry up during dry seasons as the water drains out through hillside springs, which are fairly common and usually occur at or just above a coal bed.

Wells obtaining water from the consolidated deposits generally yield from 1 to $3 \mathrm{gpm}$. A well yielding more than $5 \mathrm{gpm}$ is rather rare. Wherever coal is mined within 500 feet of the surface, the overlying rocks may be partially or completely drained of water. Wells drilled to a depth of more than 200 feet below the level of the Ohio River generally encounter salt water.

\section{Unconsolidated Deposits}

Ice sheets invaded the northern United States at least four times in the Pleistocene epoch. None of the ice sheets reached the Wheeling-Steubenville area, but the southernmost limit reached by the fourth--the

Wisconsin-is not far north of the area. Evidence indicates that one or more of the earlier ice sheets invaded northeastern Ohio and northwestern Pennsylvania.

Before the advance of the ice sheets the drainage system of the region was somewhat different than that which exists today. The upper Ohio River originally flowed northward in a valley similar to the present valley, but at a higher elevation. As ice advanced from the north and blocked the outlet, water was ponded in the valley until it reached a height sufficient to overflow a divide that lay to the south. Eventually the channel through the divide and the channel north of it were cut down sufficiently to permanently reverse the direction of the flow of the river. Once this reversal had taken place, the valley became a channel for melt water from the glaciers, and the valley was further deepened. During the Wisconsin glaciation the valley was partially filled by deposits of sand and gravel carried from the north by the melt water.

These deposits of glacial-outwash material occur from wall to wall and underlie the river. Subsequent to the glaciation the Ohio River cut a channel into the sand and gravel. This channel is narrower than the old valley and swings from one side of the valley to the other. Consequently, terraces remain above river level but occur first on one side of the river and then on the other. The terraces are essentially continuous. The terraces have been covered by Recent deposits of silt and clay left by the river during periods of flood. The map, plate 1 , shows the area underlain by these alluvial deposits.

\section{Description of the deposits}

The glacial-outwash and flood deposits together are from 40 to 80 feet thick. The bedrock floor beneath the glacial deposits slopes gently to the south. Elevations of the bedrock floor beneath the alluvium range from 
about 595 feet above sea level at Steubenville to about 574 feet above sea level at Moundsville.

The glacial-outwash deposits are poorly sorted mixtures of sand and gravel from 25 to 40 feet thick. The grain size of the material ranges from very fine sand to coarse gravel 1 to 2 inches in diameter. There are no extensive, thick layers of either sand or gravel. The overlying clay and silt is from 1 to 40 feet thick.

Figure 17 shows two cross sections of the Ohio River Valley; each shows a terrace on one side of the river. Although both sections are near Wheeling, essentially the same conditions occur along the entire length of the river in the area considered, and the cross sections are typical for the Wheeling-Steubenville area. Selected well logs, believed to show typical conditions, are given below.
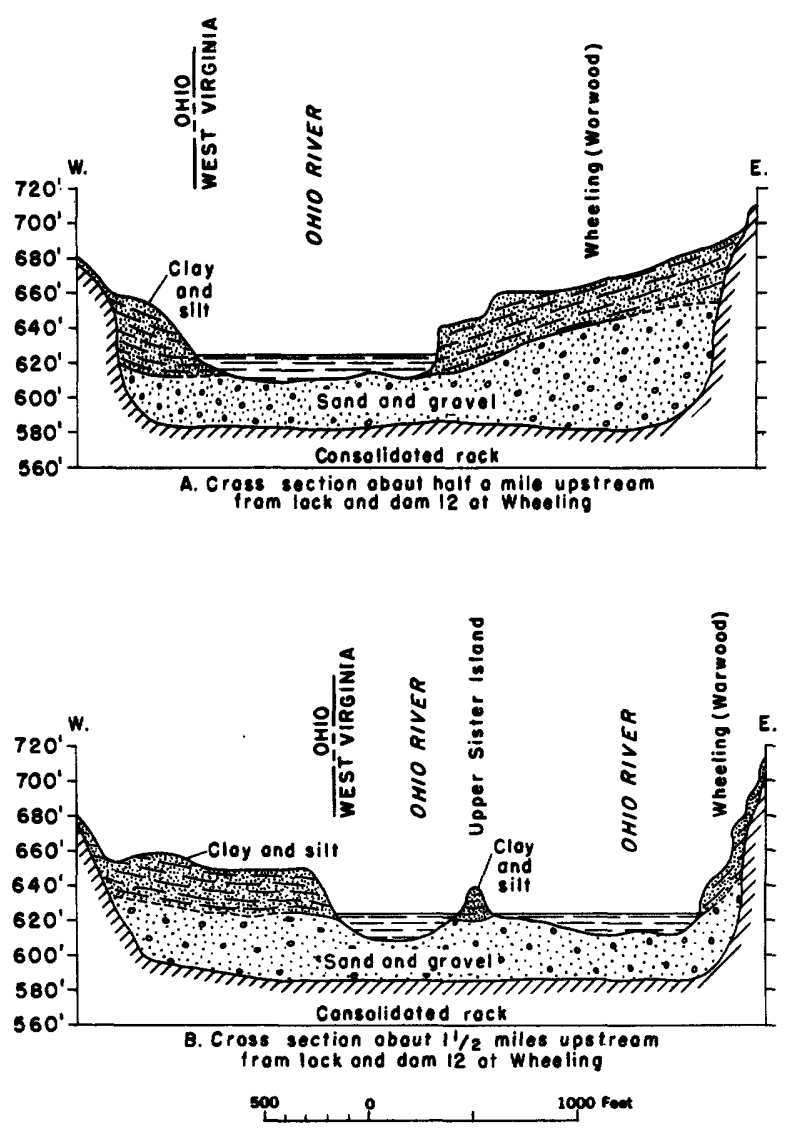

Figure 17, - Generalized cross sections of the Ohio River Valley showing the occurrence of the unconsolidated deposits.

The river flows on sand and gravel for nearly its entire length in the area, but in a few places the bottom of the channel is covered by what can best be described as organic mud. These muds are the result of an accumulation of sediment from the many wastes carried by the river. Thickness of the muds ranges from only a few inches to several feet. They have been deposited primarily in quiet backwaters, such as the back channel between Wheeling Island and Bridgeport.
Logs of selected wells

Wheeling Steel Corp., Steubenville, Ohio, well 4.

Drilled: September 1942.

Yield when drilled: $1,500 \mathrm{gpm}$ with 14 feet of drawdown. Static water level when drilled: 45.75 feet below land surface.

Land surface altitude (approx.): 660 feet above mean sea level.

$\begin{array}{rrr}\begin{array}{c}\text { Thickness } \\ \text { (feet) }\end{array} & \begin{array}{c}\text { Depth } \\ \text { (feet) }\end{array} \\ 5 & 5 \\ 22 & 27 \\ 8 & 35 \\ 10 & 45 \\ 20 & 65 \\ - & -\end{array}$

Beech Bottom Power Co., Power, W. Va., test hole 4.

Drilled: January 1929.

Static water level when drilled: 36 feet below land surface.

Land surface altitude: 662 feet above mean sea level.

\begin{tabular}{|c|c|c|}
\hline & $\begin{array}{c}\text { Thickness } \\
\text { (feet) }\end{array}$ & $\begin{array}{l}\text { Depth } \\
\text { (feet) }\end{array}$ \\
\hline Cinder and clay.... & 15 & \\
\hline Clay............................ & 5 & 2 \\
\hline Sand................................... & 10 & 3 \\
\hline $\begin{array}{l}\text { Clay and gravel.......................... } \\
\text { Sand and gravel (medium to }\end{array}$ & 5 & 35 \\
\hline 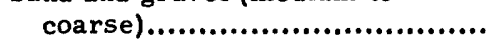 & 20 & 5 \\
\hline and $(f i n e), \ldots . . . . . . . . . . . . . . . . .$. & 5 & 6 \\
\hline and and gravel......... & 14 & 7 \\
\hline ands tone (bedrock).... & - & \\
\hline
\end{tabular}

City of Bridgeport, Ohio, well 1.

Drilled: December 1948.

Diameter: 12 inches.

Yield when drilled: $400 \mathrm{gpm}$.

Static water level when drilled: 40 feet below land surface.

Land surface altitude (approx.): 680 feet above mean sea level.

\begin{tabular}{|c|c|c|}
\hline & $\begin{array}{c}\text { Thickness } \\
\text { (feet) }\end{array}$ & $\begin{array}{l}\text { Depth } \\
\text { (feet) }\end{array}$ \\
\hline s................ & 5 & \\
\hline Clay................................... & 15 & 20 \\
\hline gravel, and silt....... & 10 & 30 \\
\hline and and gravel. & 50 & 80 \\
\hline
\end{tabular}

\section{Well data}

The earliest wells, probably dug wells, extended just a few feet below the water level and were designed to meet the needs of farm and domestic use. Depths of such wells were controlled by the depth to water level, which varies with the height of the terrace above river level. With industrial and municipal development, cased wells with screens were used, and today nearly all the 
wells in the area are cased wells drilled by percussion (cable tool) equipment or by an orangepeel type of excavator. Such wells nearly always reach bedrock. They are screened for about 30 feet through most of the wetted thickness of the aquifer. Yields of individual tubular wells are as much as $2,000 \mathrm{gpm}$ depending on size, construction, location, and age. Elsewhere in the Ohio Valley special wells with slotted pipes projecting laterally and radially from the bottom of a caisson are reported to yield 4 to $5 \mathrm{mgd}$. There are no such wells in the Wheeling-Steubenville area, but ground-water conditions are similar to areas in which such wells have been constructed.

Almost without exception the pumping history of wells in industrial well fields show that the wells decline in yield because of incrustation of the well screen and the gravel surrounding the screens. At Follansbee, $\mathrm{W}$. Va., for example, the Wheeling Steel Co, and the Koppers Co. pump an average of $10 \mathrm{mgd}$ from $10^{\prime}$ wells, but there are 8 abandoned wells in the well field. In October 1947 the water level in one well was drawn down 12 feet by pumping at a rate of $700 \mathrm{gpm}$. In July 1950 the water level in the same well was drawn down 20 feet by pumping $700 \mathrm{gpm}$.

There are two principal causes for the incrustation. The ground water generally has a rather high iron content, and iron oxides are precipitated when pumping lowers the water level and hence reduces the pressure. The iron oxides clog the pores in the gravel and the openings in the screen. The second cause of incrustation is the lowering of water levels below the top of the well screen. This allows air to enter the formation, rusts the screen, and increases the deposition of iron by bacterial action.

Chemical treatment to remove incrustants has been tried at many plants, but the results are far from satisfactory. Chemical treatment successfully cleans the screens but is not effective in removing substances that fill pore spaces in the aquifer around the screen. Mechanical methods of redevelopment, especially surging, have been found more successful. Probably the best treatment for incrusted wells would be a combination of both chemical and mechanical methods.

The water levels in the unconsolidated deposits are controlled primarily by the level of the adjacent river. In unpumped areas the ground-water level is generally about at the level of the river or a foot or so above. Under unpumped conditions ground water flows toward the river from the uplands, hence the water table slopes toward the river. The relation between the water level and river stage is shown in figure 18 .

\section{Recharge into the alluvial deposits}

Storage of water in the formation is not large because the alluvial deposits are not extensive in any one area. Recharge to the formation controls the longterm yields that can be obtained from any area.

Natural recharge occurs from precipitation on the flood plains, from ground water flowing from the bedrock at the edges of the valley, and from the river when it is in flood stage. The recharge from precipita- tion is small because the flood plains are covered by relatively impermeable clay and silt. Recharge from the bedrock is also small because most of the bedrock is dense and impermeable. Floods are probably the greatest source of natural recharge.

The large perennial yields of the well fields are obtained by induced infiltration from the Ohio River. Pumping a well or group of wells close to the river lowers the ground-water level below river level and causes = a reversal of the normal ground-water flow. Water flows from the river, into the alluvium, and towards the wells. The amount of induced infiltration available in any area, and hence the quantity of ground water available in that area, depends on the condition of the river bottom, permeability of the alluvium, thickness of the aquifers, and the distance and ground-water gradient between the wells and the source of recharge.

\section{Quality and Temperature}

The amount of water available from the consolidated rocks is very small; thus, except for domestic and very small municipal supplies, the consolidated rocks are not important. Consequently, this section is limited to a discussion of the unconsolidated deposits.

Chemical quality of water in the unconsolidated deposits varied considerably, even in wells of approximately the same depth and in the same general area (table 3). Although the mineral content of this water was lower than that of some of the small streams in the area, it was higher than that of the Ohio River (tables 1,2 , and 3). Hardness was generally high; the observed hardness ranged from 188 to $870 \mathrm{ppm}$. Ground water from the Pleistocene and Recent alluvium was more alkaline and had a higher $\mathrm{pH}$ than water from the Ohio River. A few ground-water samples contained sufficient iron to cause stains on plumbing fixtures. Manganese was also widely distributed, but in most samples it was present only in trace quantities.

The rather wide differences in the chemical character of the water from wells of approximately the same depth in the Pleistocene alluvium suggest that the wells differ with respect to their sources of recharge. Parts of the aquifer supplying heavily pumped wells favorably located may be replenished largely by infiltrated Ohio River water; those supplying wells some distance from the river or pumped at a lower rate may be recharged largely from other sources.

The mean water temperature of the wells from which samples were collected was $57^{\circ} \mathrm{F}$. These temperatures were taken in March, when ground-water temperatures are at, or near, their yearly minimum. The temperature of the ground water from pumped areas also fluctuates with changes in the temperature of the river water. Intermittent records obtained by the Wheeling Steel Co. at Follansbee show that on January 1, 1950, the temperature of the water from wells in the alluvium was $63^{\circ} \mathrm{F}$. On May 28 , it was $53^{\circ} \mathrm{F}$, and on June 28 it was $63^{\circ} \mathrm{F}$. Studies of ground-water temperature in the Parkersburg, W. Va., area during 1941-43 showed an annual range of $9^{\circ}$ to $14^{\circ} \mathrm{F}$. The temperature of the ground water in unpumped areas is fairly constant, a degree or two above the mean annual air temperature. 


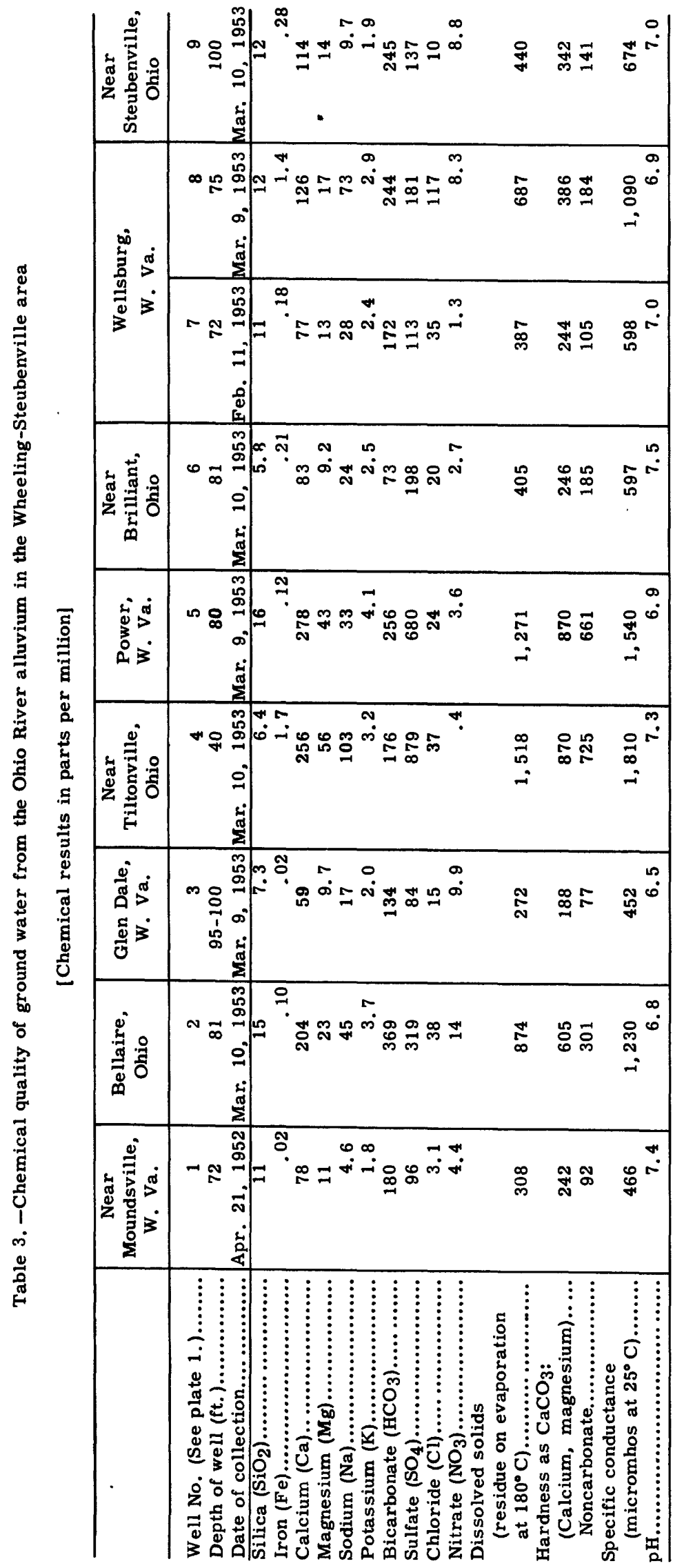




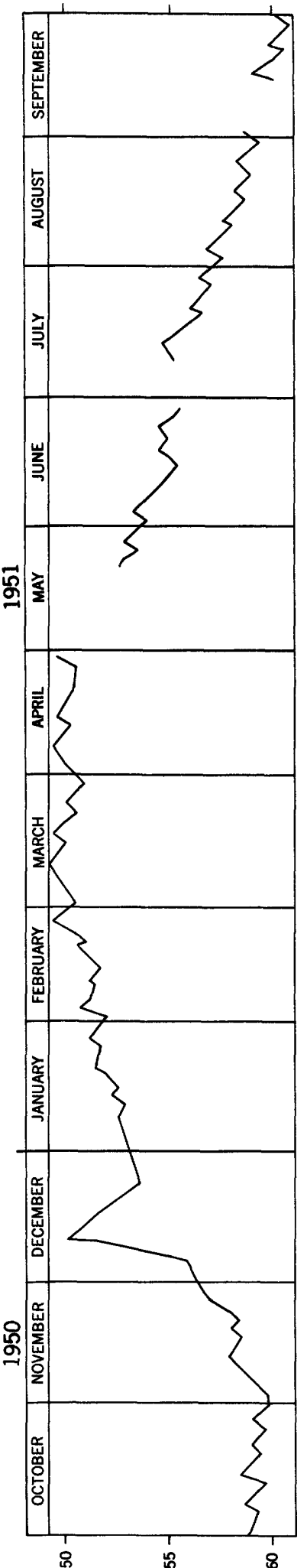

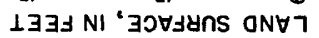

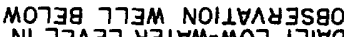
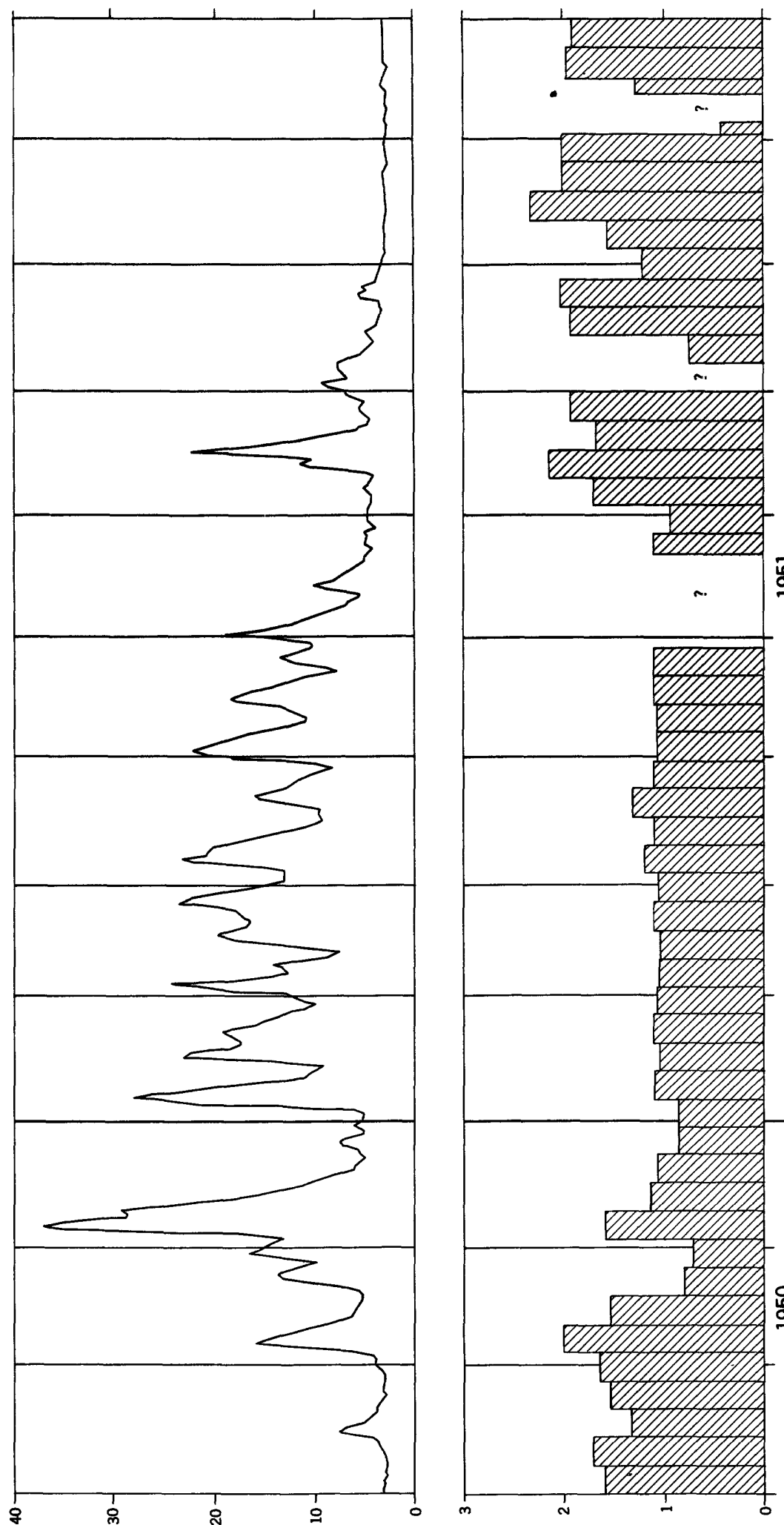

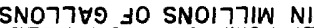

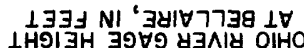

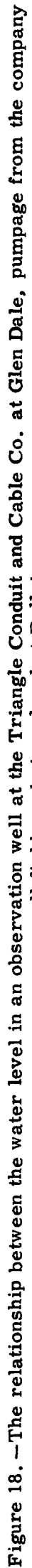




\section{PUBLIC WATER SUPPLIES}

Data concerning the public water supplies in the Wheeling-Steubenville area are listed in table 4. Table 5 and figure 19 show the chemical quality of the treated water from several of the public supplies. The reacting values of the various constituents, or concentrations expressed in equivalents per million, were used in preparation of the bar diagrams in figure 19. Equivalent per million is the number of unit equivalent weights of an ion contained in 1 million unit weights of the water. An equivalent weight of a substance is defined as the weight that is exactly equal in reaction capacity to 1 atomic weight (1.0080 grams) of hydrogen. Equivalents per million are useful in expressing chemical combinations as well as expressing analyses graphically, since one equivalent of a cation, such as sodium, will combine with exactly one equivalent of an anion, such as chloride, to form one equivalent of a compound such as sodium chloride (common table salt). The chemical quality of treated Ohio River water is satisfactory for general industrial and domestic use. However, during prolonged periods of low river flow the hardness may become fairly high. Hardness of the finished water from Wheeling's public supply ranged from slightly less than $100 \mathrm{ppm}$ to more than $300 \mathrm{ppm}$ during 1947-52. Calcium and sulfate were generally the principal mineral constituents, but during extended periods of low streamflow the sodium content sometimes exceeded that of calcium.

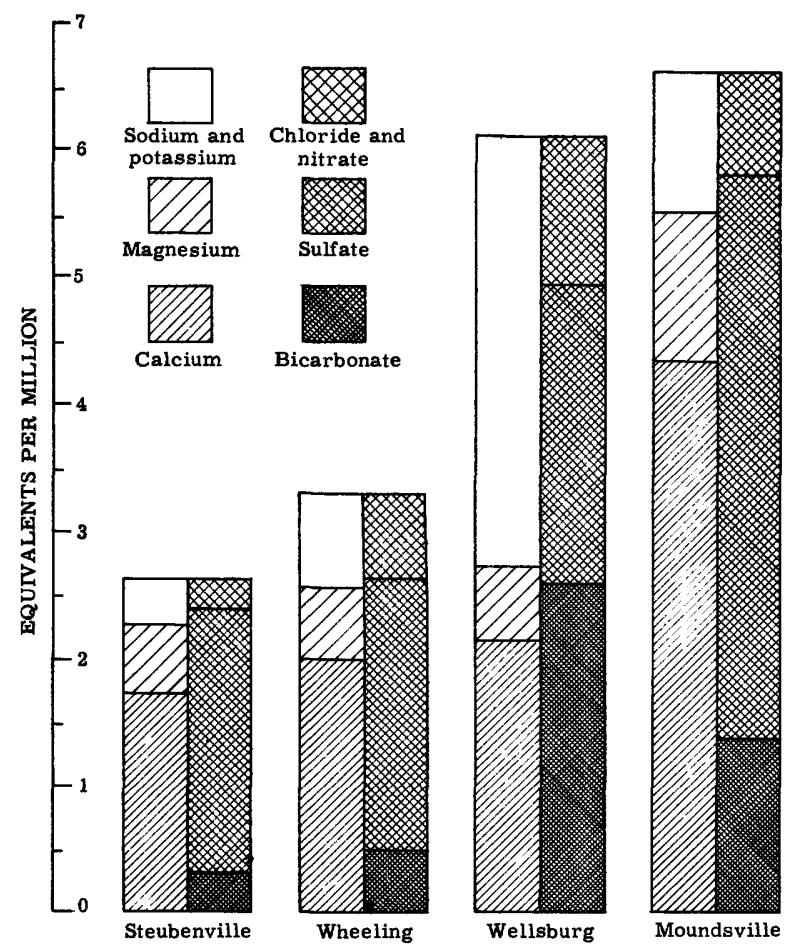

Figure 19. --Composition of water from selected public water supplies in the Wheeling-Steubenville area.

Water from wells in the alluvium contained more dissolved minerals than water from the Ohio River. The dissolved-solids content of alluvial ground water ranged from 370 to more than $600 \mathrm{ppm}$. Hardness of unsoftened water ranged from 241 to $425 \mathrm{ppm}$. (See fig. 19.) The water from wells in the consolidated deposits contained even more dissolved minerals.

Wheeling, W. Va.

Raw water from the Wheeling public supply is pumped directly from the Ohio River, aerated, superchlorinated, and treated with alum and ferrous sulfate. After sedimentation and rapid sand filtration, chlorine, chlorine dioxide, caustic soda, and sodium silicofluoride are added. The treating capacity of the plant is rated at $20 \mathrm{mgd}$.

The average use of water in Wheeling in 1952 was about $10 \mathrm{mgd}$. The peak demand was 13 million gallons in 1 day. As in so many communities, the consumption of water in Wheeling is increasing. Figure 20 was sup plied by the city engineer of Wheeling and shows the anticipated water use through the year 2000, at which time, it was estimated, the population would be 90,000 . The curve, or at least the slope of it, might be considered applicable to most of the public supplies in the area.

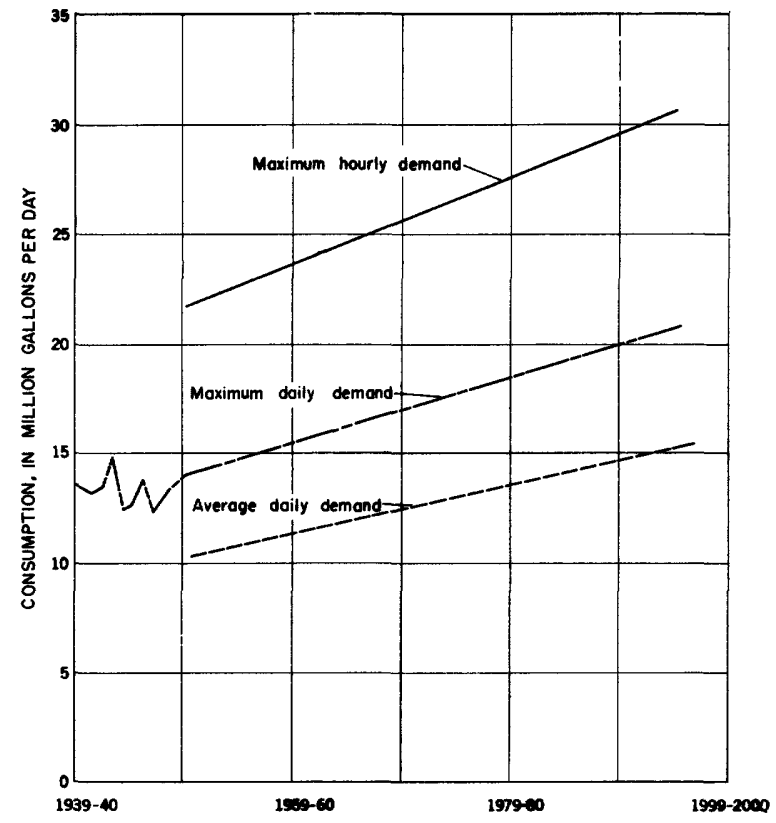

Figure 20. -Predicted increase in the demand for water from the Wheeling public supply. (After the City Engineer of Wheeling.)

\section{Other Systems}

Steubenville, Weirton, and Bellaire, like Wheeling, pump raw water from the Ohio River. Treatments of these supplies differ only in minor details from that of Wheeling. Most of the other communities in the area obtain water from wells. Some of these supplies receive no treatment other than chlorination; others are sof tened, either by the lime-soda method or by the 
WATER RESOURCES OF THE WHEELING-STEUBENVILLE AREA, WEST VIRGINIA AND OHIO

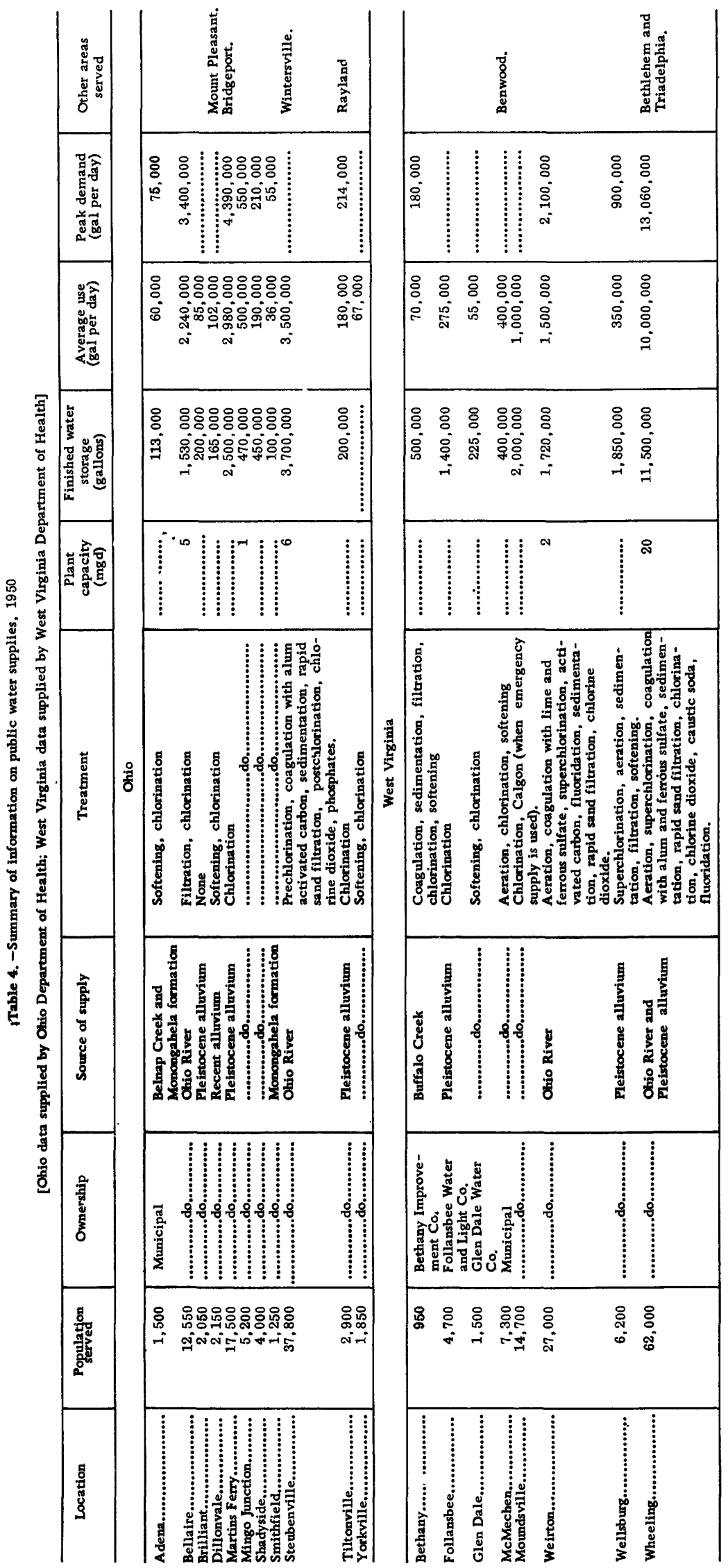




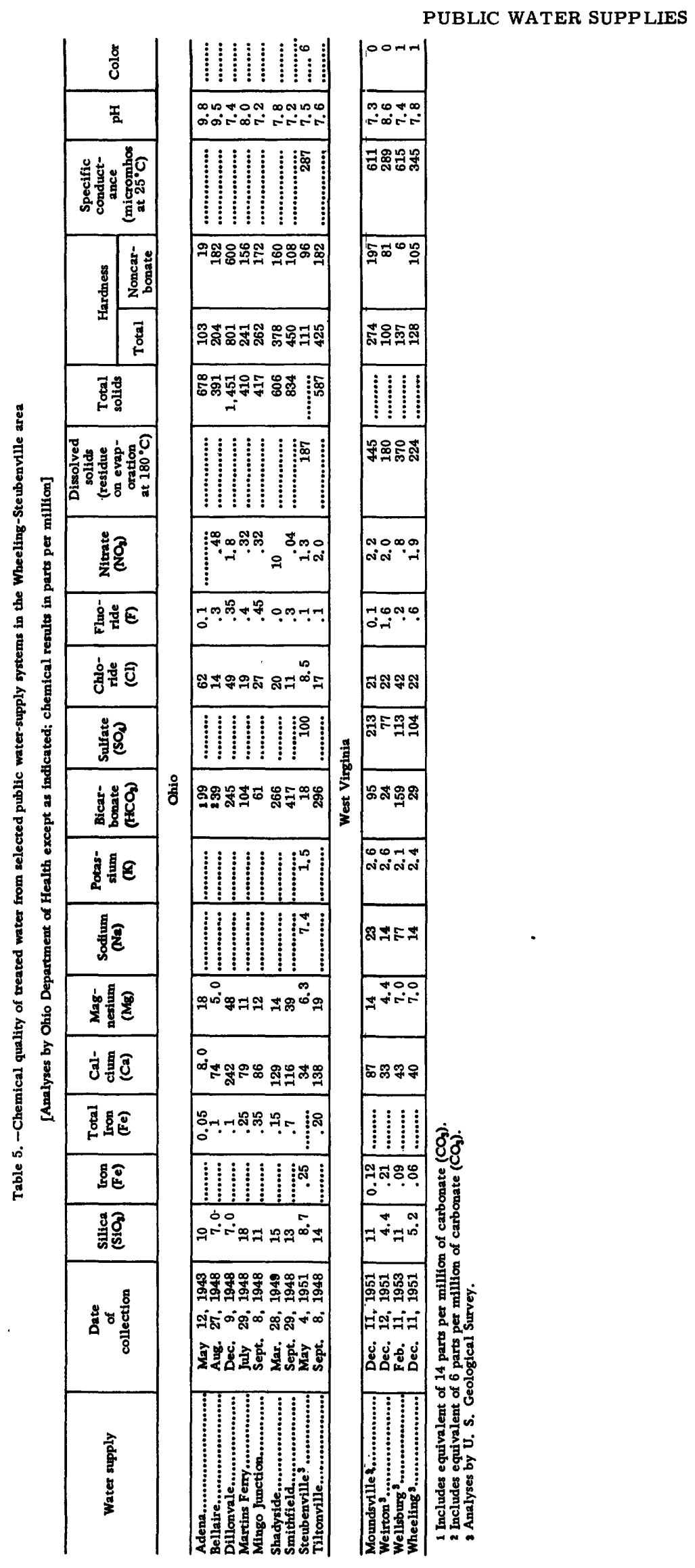


zeolite method. A few have a more extensive method of treatment.

\section{WATER DEMANDS}

The Wheeling-Steubenville area withdraws more than $953 \mathrm{mgd}$. Not more than 10 percent is consumed, as most of the water is returned to the Ohio River. The principal surface-water supplies in the area are those of Wheeling, Steubenville, Bellaire, the Beech Bottom Power Co., the Ohio Power Co., the Wheeling Steel Corp., and the Weirton Steel Co. Ground-water users withdraw slightly more than $34 \mathrm{mgd}$. Table 6 summarizes the use of water in the Wheeling-Steubenville area.

Table 6. -Summary of the use of water in the Wheeling-Steubenville area, in million gallons per day

\begin{tabular}{|c|c|c|c|c|c|c|}
\hline & \multicolumn{3}{|c|}{ Ground water } & \multicolumn{3}{|c|}{ Surface water } \\
\hline & Municipal & Industrial & Total & Municipal & Industrial & Total \\
\hline $\begin{array}{l}\text { Ohio: } \\
\text { Jefferson County } \ldots \ldots \ldots \ldots \ldots \ldots \ldots \\
\text { Belmont County } \ldots \ldots \ldots \ldots \ldots \ldots \ldots \ldots\end{array}$ & $\begin{array}{l}0.97 \\
3.17\end{array}$ & $\begin{array}{r}11.24 \\
.90\end{array}$ & $\begin{array}{r}12.21 \\
4.07\end{array}$ & $\begin{array}{l}3.56 \\
2.24\end{array}$ & $\begin{array}{c}259.14 \\
4\end{array}$ & $\begin{array}{r}262.70 \\
6.24\end{array}$ \\
\hline Total.............................. & 4.14 & 12.14 & 16.28 & 5.80 & 263.14 & 268.94 \\
\hline 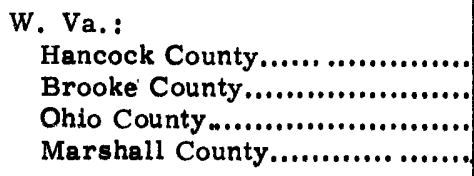 & $\begin{array}{r}. \\
1.03 \\
.34 \\
1.68\end{array}$ & $\begin{array}{r}. \\
14.65 \\
.48 \\
.72\end{array}$ & $\begin{array}{r}- \\
15.68 \\
.82 \\
2.40\end{array}$ & $\begin{array}{c}1.5 \\
10^{-} \\
-\end{array}$ & $\begin{array}{r}135 \\
504 \\
- \\
-\end{array}$ & $\begin{array}{c}136.5 \\
514 \\
- \\
-\end{array}$ \\
\hline Total............................... & 3.05 & 15.85 & 18.90 & 11.5 & 639 & 650.5 \\
\hline Grand total........................ & 7.19 & 27.99 & 35.18 & 17.30 & 902.14 & 919.44 \\
\hline
\end{tabular}

Public Water Supplies

Of the 19 municipalities that have municipal water supplies, 14 use ground-water; however, 4 of the 5 using surface water supplies are the largest cities and consequently more than 70 percent of the water used for public supplies is from surface sources. Several of the municipal supplies serve industries. Although the amount of public water used by industry is not known, a fair estimate can be made by comparing the population served and the average consumption at the various locations shown in table 4. For example, Mingo Junction uses an average of 500,000 each day, and Follansbee uses an average of 275,000 gallons each day. Mingo Junction serves 5,200 people and Follansbee serves 4,700 people.

\section{Private Industrial Water Supplies}

The largest users of water in the WheelingSteubenville area are the industries (see table 6). Far more water is used by the various plants than is used by the municipalities, and nearly all have developed their own supplies. Ninety-six percent of the total quantity used by industries is from the Ohio River, but most use some ground water, and the smaller indus tries rely entirely on ground water.

Surface water is used largely for cooling in steam generation of power. The Beech Bottom Power Co. at Power, W. Va., uses $504 \mathrm{mgd}$. The Ohio Power Co. at Brilliant, Ohio, uses an average of $144 \mathrm{mgd}$. The Wheeling Steel Corp. has developed a water system at each of its plants in the area. Their combined use is about $80 \mathrm{mgd}$. The Weirton Steel Co. in Weirton, W. Va., uses about $135 \mathrm{mgd}$.
Ground water is used for a wide variety of purposes in the area including cooling, especially when the river water is warm; boiler-feed water; process water; washing; and ice manufacture. The companies that use large quantities of surface water use ground water when more sanitary or colder water is needed. Smaller companies use ground water for all of their needs. Many companies using less than $1 \mathrm{mgd}$ have developed ground-water supplies. The largest industrial users of ground water are the Liberty Paper Board Co. in Steubenville, Ohio, an average of $4.3 \mathrm{mgd}$; the Ohio Power Co. at Brilliant, Ohio, an average of $1.2 \mathrm{mgd}$; the Wheeling Steel Corp. and the Koppers Co. at Follansbee, W. Va., a combined average of $10 \mathrm{mgd}$; and the Beech Bottom Power Co, at Power, W. Va., an average of $2 \mathrm{mgd}$.

\section{Rural Supplies}

Rural users outside the areas served by municipal supplies depend on ground water from wells in the consolidated rocks and from springs. Because many of the wells and springs dry up or their yields greatly diminish during the summer months, most of the people in rural areas also have cisterns.

\section{POTENTIAL WATER SUPPLY}

Small additional demands for water from public water-supply systems can be met without expanding existing facilities. For example, Wheeling has a filter plant capacity of $20 \mathrm{mgd}$, while the maximum used during 1952 was $13 \mathrm{mgd}$. Among the larger cities for which data are available (table 4) the total of the plant capacities exceeds the total of the peak demands by about 11 
mgd. Far more water is available by developing new systems or expanding the old.

The Wheeling-Steubenville area uses for all purposes less than 3.5 percent of its average surfacewater supply. This is clearly shown by figure 21 . Even when the flow of the Ohio River is as low as that equaled or exceeded 99 percent of the time, the present total use is only 36 percent of the flow, and navigation dams form long, narrow lakes that make impounded water available to the users. Some additional flow may be available from storage provided for low -flow augmentation in the flood-control reservoirs. Seventy percent of the water demand is for cooling purposes in the steam-power plants of the area. Cooling water used by the power plants is immediately returned to the river and is available for reuse; the only change is a slight rise in temperature. Part of the surface water used for purposes other than power production is returned to the streams in the discharge from industrial plants and sewers.
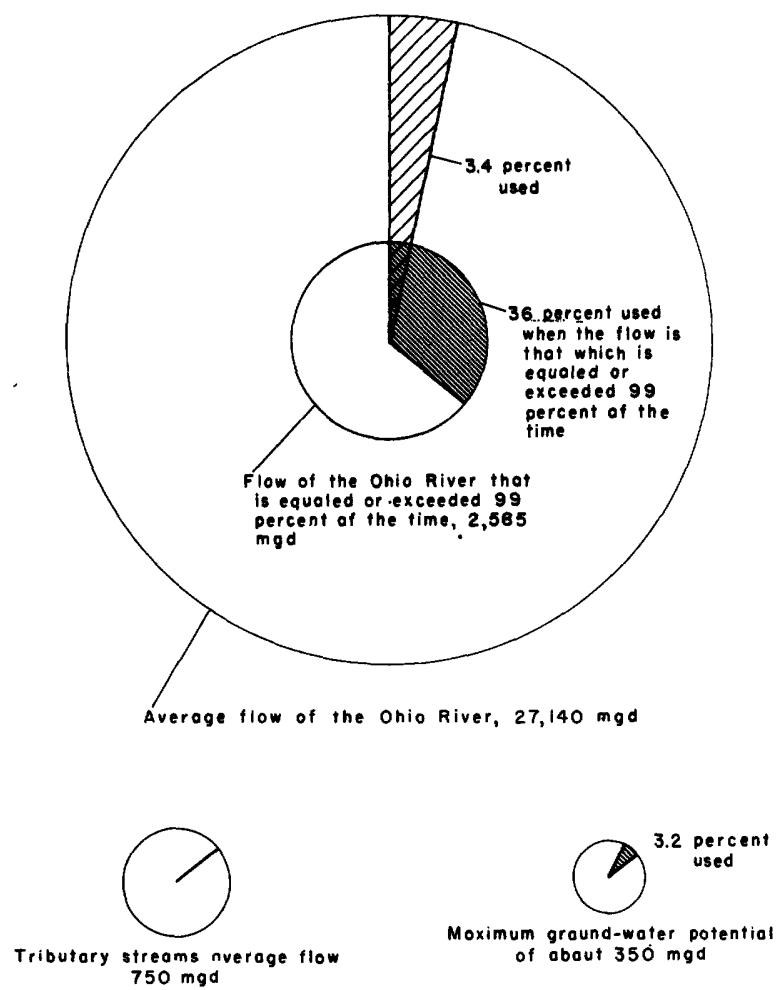

Moximum graund-water potentia $750 \mathrm{mgd}$

Figure 21. - Potential supply and present use of water in the Wheeling-Steubenville area.

Although the Ohio River is a potential source of large quantities of water, it is also the source of damage from flooding. Almost the entire flood plain of the river was inundated by the floods of 1913 and 1936. Even though several flood-control reservoirs have been constructed since 1936, damaging floods are still a possibility in the area. Therefore, industries in most parts of the flood plain are subject to occasional flooding unless protected by floodwalls or levees.
The tributaries of the Ohio River in this area have drainage areas averaging approximately 140 square miles. The flow in these small streams would be sufficient for many uses, even during periods when the flow is so low that it would be exceeded 99 percent of the time. Also, the minimum flow, if insufficient, could be increased by impoundment. If it were not for the nearness of the Ohio River, with its larger, more reliable flow and lower concentration of dissolved solids, the water from these streams would probably be used to a greater extent. Water from the small streams has a higher concentration of dissolved solids than water from the Ohio River and therefore is less desirable for many uses.

The flows of the major Ohio River tributaries that are equaled or exceeded 99 percent of the time are shown in the following tabulation:

\begin{tabular}{|c|c|c|}
\hline Stream & $\begin{array}{l}\text { Drainage } \\
\text { area } \\
\text { (sq mi) } \\
\end{array}$ & $\begin{array}{l}\text { Flow that } \\
\text { would be } \\
\text { exceeded } \\
99 \text { percent } \\
\text { of the time } \\
\text { (mgd) }\end{array}$ \\
\hline hio: & & \\
\hline $\begin{array}{l}\text { Cross Creek....................... } \\
\text { Short Creek...................... } \\
\text { Wheeling Creek.................. }\end{array}$ & $\begin{array}{l}128 \\
147 \\
108\end{array}$ & $\begin{array}{l}1.3 \\
3.2 \\
1.4\end{array}$ \\
\hline $\begin{array}{l}\text { W. Va.: } \\
\text { Buffalo Creek................... } \\
\text { Cross Creek.................... } \\
\text { Grave Creek..................... } \\
\text { Wheeling Creek................ }\end{array}$ & $\begin{array}{r}162 \\
76 \\
75 \\
297\end{array}$ & $\begin{array}{l}2.0 \\
4.4 \\
.02 \\
.5\end{array}$ \\
\hline
\end{tabular}

The potential supply of ground water in the WheelingSteubenville area is limited almost entirely to that which can be obtained by induced infiltration from the alluvium in the valley of the Ohio River. The bedrock aquifers and the thin alluvial deposits in the valleys tributary to the Ohio River are favorable sources only for small supplies.

The greatest advantage in developing a ground-water supply by induced infiltration is that the water has a more uniform quality and temperature than surface water. The water thus developed is a mixture of river water and ground water, and its quality and temperature depend on the proportion of river water in the mixture. The sands and gravels, through which the water moves on its path between the river and the wells, filter and purify the water. Large quantities of water such as are required for processing steel or for cooling in a steam-electric power-generation plant are not available from wells in the area, but quantities large enough to supply municipal needs and the needs of industries requiring less than 10 to $15 \mathrm{mgd}$ are available.

The total potential quantity of ground water available from the alluvium is far greater than the amount currently used. From indirect evidence and pumping tests conducted at Wheeling, it is believed that 5 to $10 \mathrm{mgd}$ is perennially available by induced infiltration in each mile of alluvial terrace along the river's edge. About 34 miles of river front can be considered as favorable for the development of large ground-water supplies. 
Thus, it is estimated that there is a maximum potential of about $350 \mathrm{mgd}$ available. It must be pointed out that this water comes from the river, and it is only because there is such a large surface source available to recharge the alluvium that such a potential supply of ground water could be developed.

\section{WATER LAWS}

Water laws, whose origin are legislative enactments, deal almost entirely with navigation, pollution, and flood control. Applicable laws are both Federal and State. Generally the use of water has been governed by what may be called common law, a system of law arising from custom and usage, the existence of which is usually proved by showing that it has been affirmed by the courts.

\section{Federal Laws}

Navigable streams are under the jurisdiction of Congress through its contitutional powers to "... regulate commerce... among the several States." This power extends to non-navigable tributaries of streams if the navigable capacity of the waterway or interstate commerce is affected. Flood control is also recognized as a Federal responsibility.

Control of navigable waters has been generally exercised by the Corps of Engineers, U. S. Army. The Pittsburgh District Office of the Corps of Engineers has jurisdiction in this area and should be consulted when any encroachment on a navigable stream is contemplated.

\section{Ohio Laws}

The Conservancy Act of Ohio and the Water Pollution Control Act of Ohio are the two principal water laws relating to Ohio. The Conservancy Act sets up the procedure for the establishment of a Conservancy District and describes the powers and duties of such a district. The purpose of the act is "...to prevent floods, to protect cities, villages, farms and highways from inundation, to authorize the organization of drainage and conservation districts, water supply districts and to provide for the disposal of liquid wastes." The Water Pollution Control Act created a Pollution Control Board whose purpose is to develop programs for the prevention, control, and abatement of new or existing pollutions of the waters of the State. It is unlawful to discharge any sewage, industrial waste, or other wastes into the waters of the State without first obtaining a permit issued by the board. The Division of Wildlife, Ohio Department of Natural Resources, must approve any planned obstruction that is to be placed in any stream.

The Ohio courts have ruled that a landowner is free to make whatever use of the ground water beneath his land he will, regardless of whether he cuts off the supply of another. Separate court decisions have ruled that a person is free to dig a well, to excavate for a building, or to operate a mine anywhere on his property and in doing so he is not liable for causing the spring or well of a neighbor to go dry.

\section{West Virginia Laws}

The West Virginia State Water Commission, created in 1929, is responsible for regulating stream pollution from any source affecting any of the rivers or streams in the State. Permits must be obtained from the Water Commission to install sewers, disposal systems, or treatment works, or to increase the load on existing facilities to an extent that would cause material stream pollution.

Circuit courts have jurisdiction over the establishment, organization, and operation of drainage districts for draining or improving low, wet, or overflowed land, for preventing the inundation of land, and for protecting towns, municipalities, and cities from floods. Such improvements must not impair navigation and must result in public benefit or promote public health.

The West Virginia Public Service Commission has jurisdiction over all dams in the State that are more than 10 feet high and must approve plans and specifications.

The West Virginia Conservation Commission must be informed of any obstruction that is planned to be placed in any stream in order that the Commission may pass upon the plans insofar as they may affect fish propagation.

\section{Ohio River Compact}

Both Ohio and West Virginia are members of the Ohio River Valley Water Sanitation Compact, drawn up in 1940 between the States of Illinois, Indiana, Kentucky, New York, Ohio, Pennsylvania, Tennessee, Virginia, and West Virginia. This compact, as stated in its name, is drawn up for the purpose of reducing and controlling pollution of the Ohio River.

\section{BIBLIOGRAPHY}

Cross, W. P., and Bernhagen, R. J., 1949, Ohio streamflow characteristics-Part I, Flow duration: Ohio Dept. of Nat. Res., Div. of Water, Bull. 10.

Cross, W. P., and Webber, E. E., 1950, Ohio streamflow characteristics-Part 2. Water supply and storage requirements: Ohio Dept. of Nat. Res., Div. of Water, Bull. 13.

Grimsley, G. P., 1907, County Reports-Ohio, Brooke, and Hancock Counties: W. Va. Geol. Survey.

Hennen, R. V., 1909, County Reports-Marshall, Tyler, and Wetzel Counties: W. Va. Geol. Survey.

Jeffords, R. M., 1945, Ground-water conditions along the Ohio Valley at Parkersburg, W. Va, : W. Va. Geol. Survey Bull. 10.

Kazmann, R. G., 1948, River infiltration as a source of ground-water supply: Am. Soc. of Civil Engineers Trans., v. 113, p. 404-424.

Mitchell, W. D., 1950, Water-supply characteristics of Illinois streams: Springfield, Ill., Ill. State Dept. of Public Works and Bldgs., Div, of Waterways. 
Newberry, J. S., 1878, Geology of Jefferson County: Ohio Geol. Survey, v. 3, pt. 1, p. 716-780.

Ohio Department of Health, 1949, Analyses of all municipal water supplies in Ohio.

Ohio River Valley Water Sanitary Commission, 1950 , Pollution patterns in the Ohio River.

Report of the President's Water Resources Policy Commission, 1950, Ten rivers in America's future: v. 2 .

Rorabaugh, M. I., 1948, Ground-water resources of the northeastern part of the Louisville area, Kentucky: City of Louisville, Louisville Water Co., Ky.

Sanderson, E. E., 1948, Sedimentation of reservoirs in Ohio: Ohio Water Res. Board, Dept. of Public Works, Bull. 17.

Stevenson, J. J., 1878, Geology of Belmont County: Ohio Geol. Survey, v. 3, pt. 1, p. 261-287.

Stout, Wilber, Ver Steeg, Karl, and Lamb, G. F., 1943, Geology of water in Ohio: Ohio Geol. Survey, 4 th ser., Bull. 44.

United States Corps of Engineers, 1935, The Ohio River: Washington, D. C., 5 th ed.
United States Corps of Engineers, 1950a, Corps of Engineers in Ohio: Cincinnati, Ohio, Corps of Engineers, Ohio River Div.

1950b, Corps of Engineers in West Virginia: Cincinnati, Ohio, Corps of Engineers, Ohio River Div.

1952, Definite project report, flood protection Wheeling (North-South)-Benwood, W. Va.: Pittsburgh, Fa., Corps of Engineers, Pittsburgh Dist.

1953, Water resources development by Corps of Engineers in West Virginia: Cincinnati, Ohio, Corps of Engineers, Ohio River Div.

United States Department of Agriculture, 1941, Climate and man: U. S. Dept. of Agriculture Yearbook.

United States Geological Survey, issued annually, Surface-water supply of the United States, pt. 3, Ohio River Basin: U. S. Geol. Survey Water-Supply Papers.

West Virginia State Department of Health, 1951, Public water supplies in West Virginia: Charleston, W. Va. (Revised.) 